\title{
Integration of Salmonella into Combination Cancer Therapy
}

\author{
Besan H. Al-Saafeen ${ }^{1}$, Maria J. Fernandez-Cabezudo ${ }^{2}$ and Basel K. al-Ramadi ${ }^{1,3, *}$ \\ 1 Department of Medical Microbiology and Immunology, College of Medicine and Health Sciences, \\ United Arab Emirates University, Al Ain 17666, United Arab Emirates; 201970008@uaeu.ac.ae \\ 2 Department of Biochemistry and Molecular Biology, College of Medicine and Health Sciences, \\ United Arab Emirates University, Al Ain 17666, United Arab Emirates; mariac@uaeu.ac.ae \\ 3 Zayed Center for Health Sciences, United Arab Emirates University, Al Ain 17666, United Arab Emirates \\ * Correspondence: ramadi.b@uaeu.ac.ae
}

check for updates

Citation: Al-Saafeen, B.H.;

Fernandez-Cabezudo, M.J.;

al-Ramadi, B.K. Integration of

Salmonella into Combination Cancer

Therapy. Cancers 2021, 13, 3228.

https: / / doi.org/10.3390/

cancers 13133228

Academic Editor: Esther Julián

Received: 10 May 2021

Accepted: 24 June 2021

Published: 28 June 2021

Publisher's Note: MDPI stays neutral with regard to jurisdictional claims in published maps and institutional affiliations.

Copyright: (c) 2021 by the authors. Licensee MDPI, Basel, Switzerland. This article is an open access article distributed under the terms and conditions of the Creative Commons Attribution (CC BY) license (https:// creativecommons.org/licenses/by/ $4.0 /)$.
Simple Summary: Despite significant advances in the development of new treatments, cancer continues to be a major public health concern due to the high mortality associated with the disease. The introduction of immunotherapy as a new modality for cancer treatment has led to unprecedented clinical responses, even in terminal cancer patients. However, for reasons that remain largely unknown, the percentage of patients who respond to this treatment remains rather modest. In the present article, we highlight the potential of using attenuated Salmonella strains in cancer treatment, particularly as a means to enhance therapeutic efficacy of other cancer treatments, including immunotherapy, chemotherapy, and radiotherapy. The challenges associated with the clinical application of Salmonella in cancer therapy are discussed. An increased understanding of the potential of Salmonella bacteria in combination cancer therapy may usher in a major breakthrough in its clinical application, resulting in more favorable and durable outcomes.

Abstract: Current modalities of cancer treatment have limitations related to poor target selectivity, resistance to treatment, and low response rates in patients. Accumulating evidence over the past few decades has demonstrated the capacity of several strains of bacteria to exert anti-tumor activities. Salmonella is the most extensively studied entity in bacterial-mediated cancer therapy, and has a good potential to induce direct tumor cell killing and manipulate the immune components of the tumor microenvironment in favor of tumor inhibition. In addition, Salmonella possesses some advantages over other approaches of cancer therapy, including high tumor specificity, deep tissue penetration, and engineering plasticity. These aspects underscore the potential of utilizing Salmonella in combination with other cancer therapeutics to improve treatment effectiveness. Herein, we describe the advantages that make Salmonella a good candidate for combination cancer therapy and summarize the findings of representative studies that aimed to investigate the therapeutic outcome of combination therapies involving Salmonella. We also highlight issues associated with their application in clinical use.

Keywords: Salmonella; cancer; combination therapy; immunotherapy

\section{Introduction}

It is a well-known fact that cancer is a major public health concern worldwide, with nearly 10 million deaths attributed to this chronic disease each year [1]. Although chemotherapy and radiotherapy remain the "gold standard" for cancer treatment, they have been associated with inherent limitations including (a) lack of tumor selectivity and inadequate tissue penetration, (b) high toxicity to normal tissues, (c) development of resistance to treatment, and (d) tumor recurrence. In the past few years there has been unprecedented and durable success with the use of immune checkpoint blockade or chimeric antigen receptor T cell therapies (CAR-T) in treating cancer [2]. However, the clinical application of such approaches has encountered several challenges in association with the low response rate among treated patients in addition 
to the development of immune-related adverse effects [3]. These obstacles reduce the capacity of cancer therapies to achieve the optimum therapeutic outcome and therefore underscore the increasing demand to develop better strategies for cancer treatment.

Bacterial-mediated cancer therapy (BMCT) was recognized in the 19th century when Vautier first noticed tumor regression in cancer patients with gas gangrene [4]. Subsequently, William Coley succeeded in utilizing heat-inactivated Streptococcus pyogenes and Serratia marcescens to treat inoperable tumors, providing BMCT as one of the first examples of cancer immunotherapy $[5,6]$. Despite the achieved success, BMCT gradually disappeared from clinical use due to criticisms of Coley's toxin along with the rise of chemotherapy and radiotherapy as effective cancer treatments. The development of molecular biology in addition to the increased understanding of host-pathogen interactions and tumor biology reinspired the interest of researchers toward utilizing bacteria as an anti-cancer therapeutic agent. Outstanding and promising candidates for BMCT include Bacillus Calmette-Guerin, Listeria monocytogenes, Salmonella enterica serovar Typhimurium (hereafter S. typhimurium), Clostridium novyi-NT, and Escherichia coli [7-11]. Several lines of evidence have documented the anti-tumor efficacy of the facultative anaerobic Salmonella in addition to its oncolytic capacity and immunomodulatory effects [12-18]. Besides, Salmonella possesses advantages in the preferential colonization and proliferation in tumor tissues [19], thus overcoming the major limitation associated with conventional cancer treatments. Moreover, the engineering plasticity of Salmonella considerably enhances its therapeutic potential through improving safety, increasing tumor targeting, and delivering anti-tumor agents [20,21]. Given these advantages, Salmonella has been utilized in combination with other approaches to cancer therapy, including chemotherapy, radiotherapy, and immune checkpoint inhibitors, in order to compensate for their respective deficiencies and to improve the overall therapeutic efficacy. The topic of Salmonella in cancer therapy has been covered in other recently published reviews [20,22-25].

In the current review, we describe the unique aspects of Salmonella as an anti-cancer therapeutic agent and summarize the present research on the combination of Salmonella with other approaches to cancer therapy, considering issues that would impact its clinical translation.

\section{Unique Aspects of Salmonella in Cancer Therapy}

There are several properties of Salmonella organisms that make them suitable candidates for use in cancer therapy. These are highlighted in Figure 1 and discussed in the following sections.

\subsection{Selective Tumor Colonization}

Salmonella are facultative anaerobic intracellular pathogens that exhibit strong preferential colonization in tumor tissues. In pre-clinical models, $S$. Typhimurium enrichment within tumors was $>1000$ fold greater than that observed in the usual target organs, including the spleen and liver $[19,26]$. Following administration, the bacterial colonization level in tumors was comparable to that of other tissues [21]. However, this similarity in the initial levels was disrupted within hours to days due to bacterial clearance from the circulatory system and other usual target organs, while bacterial proliferation continued within tumor tissues [21]. The mechanism(s) underlying selective tumor colonization is still not completely understood. It is thought that the hypoxic and poorly vascularized conditions within tumor tissues are more favorable to the colonization and proliferation of Salmonella [20]. This is consistent with Salmonella's preferential colonization in necrotic regions, where essential nutrients are available and clearance by the immune system is impaired [27]. Interestingly, bacterial accumulation was not observed in other hypoxic non-tumor tissues, highlighting the contribution of other factors to Salmonella's tumor selectivity [27]. Several studies revealed that chemotaxis plays an essential role in the migration of Salmonella to tumor tissues [28-31]. For example, aspartate, serine, and ribose/galactose chemoreceptors were successful in initiating chemotaxis of Salmonella organisms toward 
tumor cylindroids, with penetration of tissue and induction of necrosis [29]. Furthermore, it has been shown that motility is essential for bacterial accumulation in tumor tissues [32]. However, another study proposed that the accumulation of Salmonella in tumors is influenced by the tumor microenvironment, host reticuloendothelial system, and bacterial metabolism, and is independent of its chemotactic and mobile properties [33]. A third study attributed the initial colonization in tumor tissues to tumor necrosis factor alpha (TNF- $\alpha$ ) induced by the intravenous administration of Salmonella [34]. The increased level of TNF- $\alpha$ induced an increase in blood influx to the tumor, thereby enhancing the colonization of Salmonella in tumor tissue [34].

Irrespective of the exact mechanism, the targeted distribution and proliferation of Salmonella in tumor tissues overcome the lack of tumor specificity and inadequate tissue penetration, which are the major limiting factors for the therapeutic efficacy of conventional cancer therapies. Moreover, the replication potential of this biological agent allows its administration at low dose and frequency, thereby minimizing toxicity and adverse side effects.
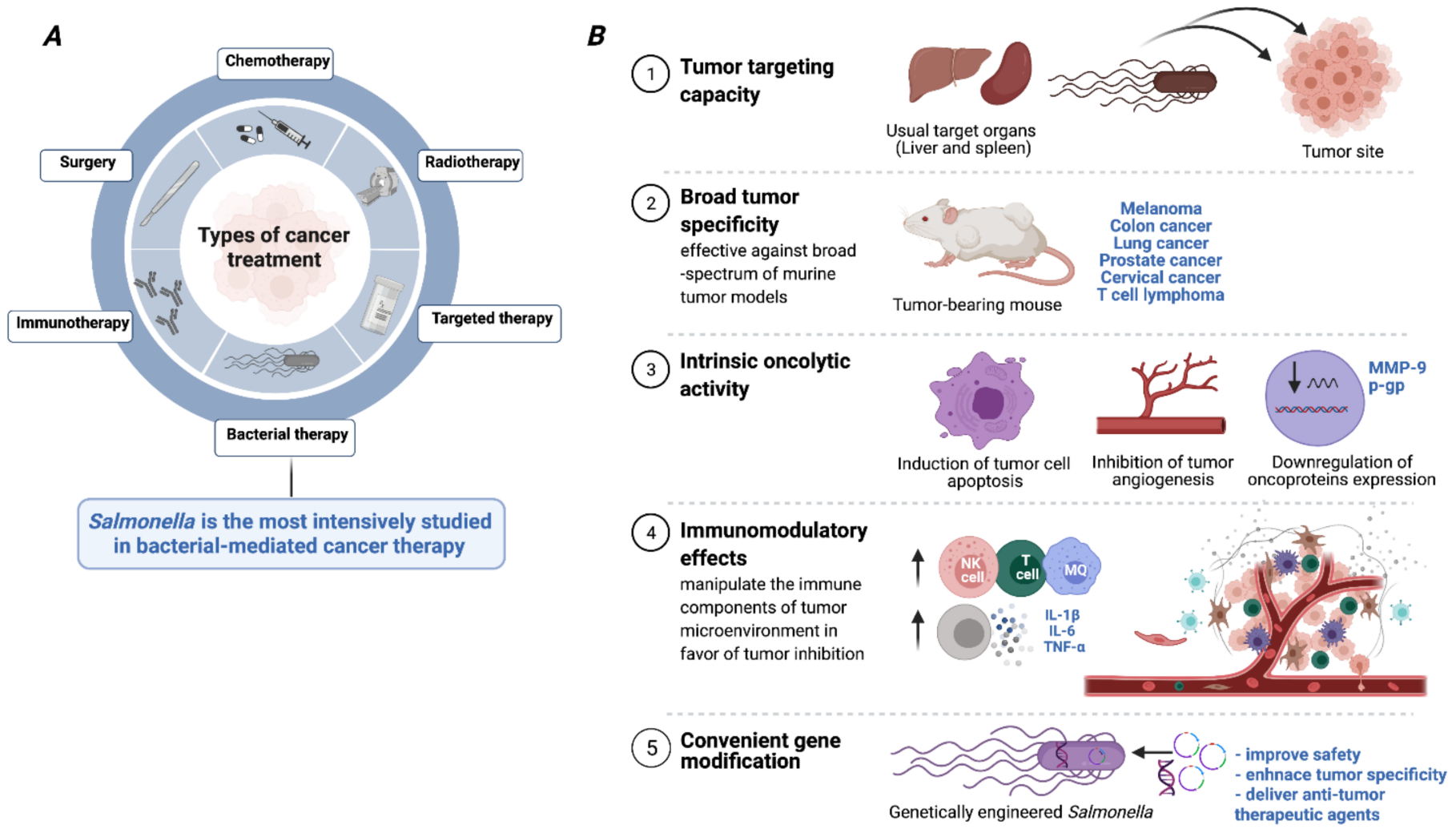

Figure 1. Salmonella characteristics that favor their use in cancer therapy. (A) The major modalities of cancer treatment. (B) The 5 key properties of Salmonella organisms that make them amenable for potential use in cancer therapy. The role of Salmonella as an anti-tumor agent has been documented against a broad-spectrum of cancers. Salmonella-mediated anti-tumor effects are delivered through its ability to preferentially colonize and proliferate in tumor tissues, induce direct tumor cell killing, and transform the tumor microenvironment from immunosuppressive to immunogenic. In addition, the engineering plasticity of Salmonella considerably enhances its efficacy in cancer therapy through improving safety, increasing specificity, and allowing the delivery of anti-tumor therapeutic agents specifically to the tumor site. 


\subsection{Broad Tumor Specificity}

Several pre-clinical studies conducted in the past decades have reported the effective therapeutic index of Salmonella. This success was achieved at the level of tumor growth, metastasis, and host survival. The effectiveness of Salmonella treatment has been documented against a broad-spectrum of murine tumor models, including melanoma [35,36], colon cancer [37], lung cancer [38], prostate cancer [39], cervical cancer [40], metastatic T cell lymphoma [41], and others. In particular, Salmonella-mediated inhibition of metastasis was observed in different tumor models such as breast cancer [42], osteosarcoma [43], and dorsal spinal cord gliomas [44]. Moreover, the anti-tumor effects of Salmonella were demonstrated in metastatic patient-derived orthotopic xenograft (PDOX) murine models of osteosarcoma [45], melanoma [46], soft tissue sarcoma [47], and follicular dendritic cell sarcoma [48]. In addition to Salmonella's efficacy against a wide range of tumor types, the different routes of Salmonella administration, including intravenous, intra-arterial, intraperitoneal, and intratumoral routes, have shown success in inhibiting tumor growth.

\subsection{Intrinsic Oncolytic Capacity}

Several studies have claimed that Salmonella-induced tumor inhibition is in part mediated by the intrinsic oncolytic activity of Salmonella itself. A variety of mechanisms underlie Salmonella's intrinsic anti-tumor activity, all of which are mediated through the induction of tumor cell apoptosis. In vitro and in vivo studies utilized Annexin V detection, caspase-3 activity, and TUNEL assays to report on increased tumor cell death following infection with Salmonella and subsequent invasion $[12,49,50]$. It was suggested that nutrient deprivation and release of bacterial toxins could underlie apoptosis promotion [51,52]. In addition, the ability of Salmonella to induce autophagy was correlated to its intrinsic anti-tumor effect $[13,53]$. In one study, Salmonella induced autophagy in melanoma tumor cells in a dose- and time-dependent manner through downregulation of the AKT/mTOR pathway [13]. Other studies reported that Salmonella could delay tumor progression by inhibiting tumor angiogenesis [54-56]. The anti-angiogenic ability of Salmonella is derived from its capacity to downregulate the expression of HIF- $\alpha$ and vascular endothelial growth factor (VEGF) through the AKT/mTOR pathway [54]. The intrinsic oncolytic activity can be also attributed to nitrate reductase enzyme released from lysed Salmonella and its role in converting nitrate and nitrite into nitric oxide, which induces apoptosis in tumor cells $[57,58]$. Moreover, Salmonella was documented to downregulate the expression of certain oncoproteins in tumor cells including p-glycoprotein (p-gp) [59] and matrix metalloproteinase 9 (MMP-9) [60], inhibiting drug resistance and tumor metastasis, respectively.

\subsection{Immunomodulatory Effects}

Along with the intrinsic oncolytic activity of Salmonella, its great ability to modulate the immune system also plays a considerable role in tumor inhibition. In this regard, it is worth mentioning that the immunosuppressive tumor microenvironment and immunosurveillance evasion mechanisms are the two major limitations in achieving effective and durable anti-cancer effects. Conventional cancer therapeutics fail to manipulate the immune component of the tumor. On the other hand, Salmonella-mediated cancer therapy shows remarkable success in modulating the tumor microenvironment in favor of tumor inhibition. In other words, Salmonella has shown its potential to shift the tumor microenvironment from immunosuppressive to immunogenic. This success is achieved through alterations in both cellular and soluble components of the immune system which, in turn, affect the phenotypic and functional properties of immune cells, as illustrated in Figure 2. 


\section{The immunomodulatory effects of Salmonella in tumor tissue}
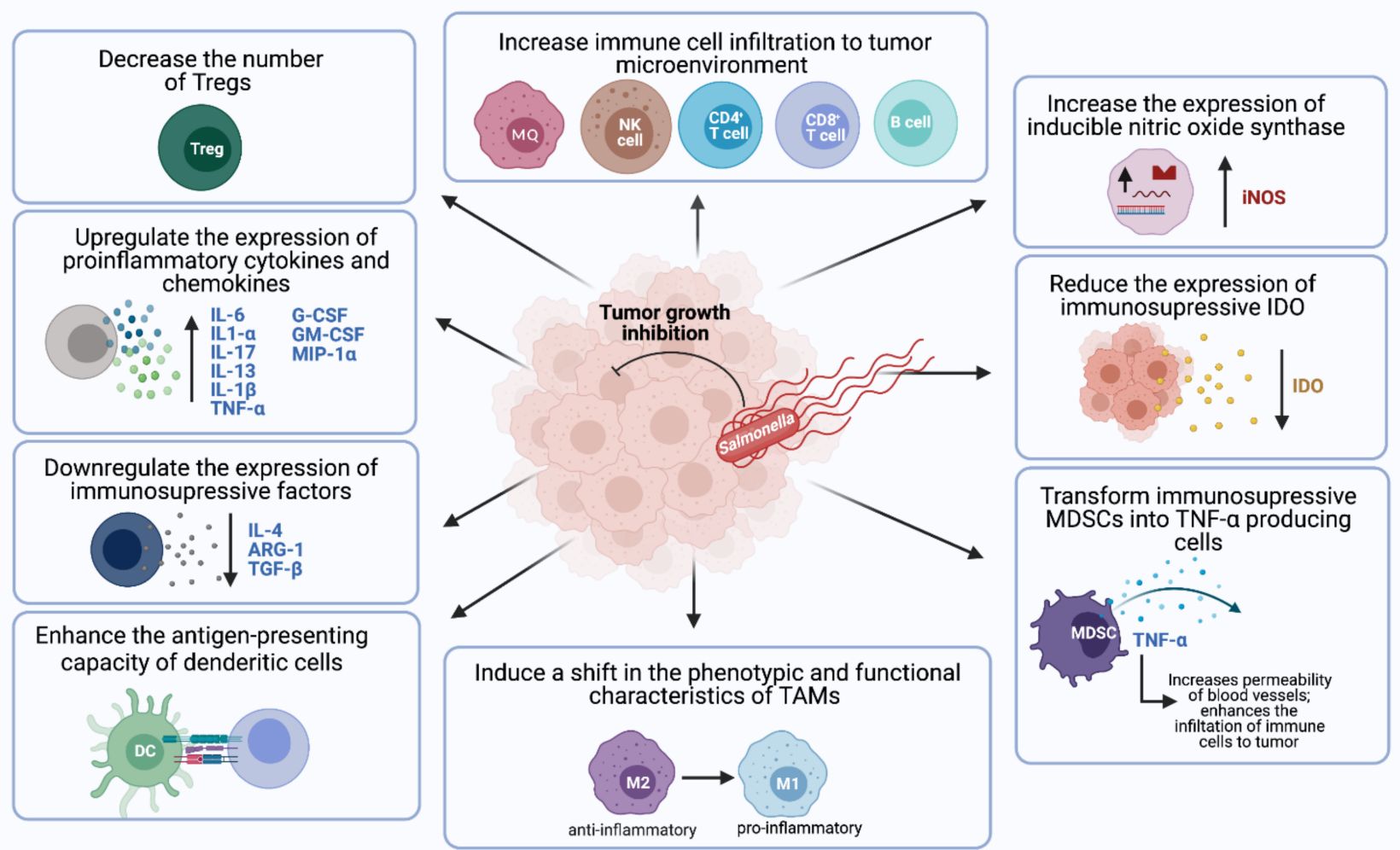

Figure 2. Schematic diagram illustrating Salmonella's capacity to manipulate immune components of tumor in favor of tumor inhibition. Transformation of the tumor microenvironment from immunosuppressive to immunogenic occurs through increased infiltration and reprograming of anti-tumor immune cells, upregulating the expression of proinflammatory cytokines and inducing a shift in the phenotypic and functional characteristics of immune cells. The references for the summarized effects are all discussed in the text. MQ: macrophage; IL-1 $\alpha$ : interleukin 1 alpha; IL-1 $\beta$ : interleukin-1 beta; G-CSF: granulocyte colony-stimulating factor; GM-CSF: granulocyte-macrophage colony-stimulating factor; MIP-1 $\alpha$ : macrophage inflammatory protein-1 alpha; ARG-1: arginase-1; TGF- $\beta$ : transforming growth factor-beta; TAMs: tumor-associated macrophages; DC: dendritic cell; M1: M1-like macrophage; M2: M2-like macrophage.

Several studies illustrated Salmonella's ability to increase the tumor-infiltration of different innate and adaptive immune cells, including macrophages [16,61], natural killer (NK) cells [17], CD4 ${ }^{+}$helper T cells $[16,17,61], \mathrm{CD}^{+}$cytotoxic T cells $[17,18,61]$, and B cells [62]. It is suggested that the recruitment of these immune cells enhances the immune response directed against tumor cells. The enhanced recruitment of neutrophils following Salmonella administration was also documented $[17,49,58,63]$, but it is still not clearly understood whether neutrophil infiltration promotes or inhibits tumor growth [64]. In addition, Salmonella organisms attenuate tumor-induced immunosuppression and inhibit tumor growth by reducing the number of regulatory T cells (Tregs) $[65,66]$. Salmonella was also reported to upregulate the expression of pro-inflammatory cytokines and chemokines, including IL-6, IL-1 $\alpha$, IL-17, IL-13, G-CSF, GM-CSF, MIP-1 $\alpha$, and others [67]. This upregulation was attributed to Salmonella's ability to activate the NF- $\kappa \mathrm{B}$ pathway [68-71]. The increased expression of the immunostimulatory factors IL- $1 \beta$, TNF- $\alpha$, and IFN- $\gamma$ as well as inducible nitric oxide synthase (iNOS) has been observed following treatment with Salmonella $[14,36,72,73]$, which is accompanied by the parallel downregulation of immunosuppressive factors such as IL-4, ARG-1, and TGF- $\beta$ [36,74]. It was also reported that Salmonella can transform the immunosuppressive myeloid-derived suppressor cells (MDSCs) into TNF- $\alpha$-producing cells [75]. In turn, TNF- $\alpha$ enhances the infiltration of im- 
mune cells to the tumor site by increasing the permeability of tumor blood vessels [34,76]. Kaimala et al. demonstrated Salmonella's ability to reduce the immunosuppressive capacity of intratumoral myeloid cells and highlighted its capacity to induce a shift in the functional characteristics of tumor-associated macrophages (TAMs) toward pro-inflammatory functions [36,61]. Consistent with these previous findings, Phan et al. (2015) illustrated Salmonella's contribution to the activation of the inflammasome pathway in association with an increase in the levels of caspase-1, IPAF, and NLRP-3 [77]. Moreover, the capacity of dendritic cells to present tumor antigens was also enhanced post treatment with Salmonella [78]. Others suggested that Salmonella is able to promote T helper 1 polarization through Toll-like receptor 4 (TLR-4), and this in turn contributes to Salmonella-mediated tumor inhibition [16]. Grille et al. (2014) reported a marked increase in the level of intratumoral NK cell activation as assessed by CD25 expression [17]. CD25 expression correlates with the cytotoxic activity of NK cells and plays an essential role in increasing the affinity for IL-2, which in turn enhances cell proliferation and production of cytotoxic molecules [79]. Another means by which Salmonella induces tumor growth inhibition is through reducing the expression of indoleamine 2,3-dioxygenase (IDO) and reversing its immunosuppressive effect [80,81]. IDO plays an important role in the activation of regulatory $\mathrm{T}$ cells and development of immune tolerance in effector tumor-infiltrating lymphocytes [82]. Most recently, studies have investigated the ability of Salmonella to alter the expression of immune checkpoints on different immune cells (discussed below). In summary, the capacity of Salmonella to alter the intratumoral immune cell repertoire in favor of tumor regression has been amply demonstrated by different groups of investigators in preclinical models.

\subsection{Ease of Gene Modification}

Although Salmonella possesses immunomodulatory and intrinsic oncolytic capacities, these advantages are not sufficient for achieving optimum therapeutic outcomes. In order to enhance the overall therapeutic index of Salmonella treatment alone or in combination with other therapies, several strains were engineered to improve the safety and potentiate anti-tumor efficacy. Salmonella's amenable gene modification helped in improving the safety of bacterial therapy through the deletion of major virulence factors or the generation of auxotrophic mutants that are incapable to replicate efficiently in an environment deficient in specific nutrients [21]. For example, deletion of msbB gene, responsible for myristoylation of an essential component of LPS, reduced Salmonella's toxicity by 10,000-fold while retaining its anti-tumor efficacy in mice [83]. It is worth bearing in mind that bacterial attenuation might occur at the expense of its ability to inhibit tumor growth, because some virulence factors underlie Salmonella's intrinsic anti-tumor properties [21]. The Salmonella A1-R strain, an attenuated leucine-arginine auxotrophic mutant, exhibited enhanced preferential colonization in tumor tissues due to the abundance of these nutrients in the tumor microenvironment but not in normal tissues [84-86]. Besides improving the safety and minimizing toxicity to normal organs, Salmonella was also engineered to enhance the antigenicity of the tumor by delivering tumor-associated or specific antigens [74]. This in turn potentiates the anti-tumor immune response in favor of tumor regression. In addition, several studies documented the unprecedented success of engineered Salmonella in transporting various anti-tumor therapeutic agents specifically to the tumor site. Salmonella has been utilized as a delivery vehicle of various cytotoxic agents (e.g., cytolysin A, PE38, and diphtheria toxin) and apoptosis-inducing proteins (e.g., Fas ligand, TRAIL, and apoptin), as well as immunomodulatory cytokines (e.g., IL-2, IL-12, IL-18, and IFN- $\gamma$ ) $[20,56,87]$. Engineering of prodrug-converting enzymes into tumor-targeting Salmonella was also reported. The payload enzyme released by Salmonella metabolizes the systemically administered pro-drug into cytotoxic agent at the tumor site only, thereby minimizing the drug-related toxic effects on normal tissues [21]. An example of prodrug-converting enzyme is cytosine deaminase (CD), which converts the non-toxic 5-flourocytosine (5-FC) into anti-tumor 5-flourouracil (5-FU). The enhanced anti-tumor efficacy of CD-expressing Salmonella was reported using in vitro and in vivo studies $[88,89]$. In this context, it is worth mentioning that the appli- 
cation of this approach in cancer patients could have some limitations because of the ability of 5-FU to freely diffuse across the cell membrane and exert its cytotoxic activity in neighboring cells [90]. Moreover, increased tumor targeting could be achieved by utilizing engineered Salmonella in order to minimize bacterial-related toxicity or enhance its therapeutic potential while keeping toxicity to minimal. For example, the surface expression of antibody fragments against specific tumor-associated antigens, including carcinoembryonic antigen (CEA) and CD20, was shown to increase Salmonella's tumor localization in murine adenocarcinoma and human lymphoma models, respectively [91,92]. In addition, Salmonella's engineering plasticity helped to integrate controlled gene expression systems into tumor-targeting bacteria. This could be achieved through either the incorporation of gene promoters responsive to tumor-associated signals, such as hypoxia-inducible promoter systems (HIP-1 and NirB) [93-95], or remotely through inducible promoters (e.g., as pBAD, pTet, and Pm) in response to exogenous transcriptional factors (e.g., L-arabinose, tetracyclines, and acetyl salicylic acid) [96-99]. This enhances tumor specificity and assures the selective expression of specific genes at the tumor site.

\section{Salmonella in Combination with Other Approaches to Cancer Therapy \\ 3.1. Combination with Chemotherapeutic Agents}

The efficacy of chemotherapy is partly limited by systemic toxicity, lack of selectivity for cancer cells, and the chances of drug resistance development. In order to overcome these limitations, the role of Salmonella in enhancing the efficacy of chemotherapeutic agents against different tumor models has been investigated. Bascuas et al. reported that the intra-tumoral administration of an attenuated strain of S. typhimurium improved the outcomes of cyclophosphamide, doxorubicin, vincristine, and prednisone (CHOP) chemotherapy in non-Hodgkin lymphoma-bearing mice, with an overall decrease in toxicity [100]. In this model, the combination therapy successfully inhibited tumor growth and prolonged animal survival compared with either treatment alone, and was associated with an increase in the percentage of $\mathrm{CD}^{+}$tumor-infiltrating lymphocytes (TILs) as well as in the cytotoxic ability of NK cells [100]. In a study using breast cancer cells, mice treated intravenously with attenuated S. typhimurium plus a low dose of doxorubicin exhibited a slower tumor growth rate in comparison to those treated with single therapy [101]. It is worth noting that mice treated with the maximum tolerated dose of doxorubicin showed greater delay in tumor growth, but this was at the cost of higher toxicity [101]. It was also suggested that Salmonella/doxorubicin combination enhances the infiltration of $\mathrm{CD} 8^{+} \mathrm{T}$ cells and Tregs to the tumor site and increases the ratio of Mo-MDSCs/G-MDSCs within spleen and tumor tissues [101]. A study conducted by Lee et al. documented that the intraperitoneal administration of attenuated Salmonella choleraesuis improved the outcome of cisplatin therapy in hepatoma- and lung tumors-bearing mice [102]. This combination induced changes in the tumor microenvironment, including an increase in the infiltrating neutrophils, CD8 ${ }^{+} \mathrm{T}$ cells, and apoptotic cells [102]. Kawaguchi and his group highlighted the ability of $S$. typhimurium A1-R to enhance the anti-tumor capacity of gemcitabine among nude mice bearing pancreatic cancer PDOX [103], although gemcitabine has limited efficacy in treating pancreatic cancer. Another group succeeded in utilizing an attenuated S. typhimurium strain VNP20009 to improve the outcome of the standard maximum tolerated dose and lose-dose metronomic cyclophosphamide chemotherapy in B16F10 melanoma-bearing mice [104]. Chen et al. also described the improved anti-tumor effect of VNP20009 combined with triptolide in a mouse melanoma model [67]. This improvement was attributed to the enhanced capacity of combination therapy to suppress tumor angiogenesis and reduce the level of serum and tumor VEGF in comparison to either treatment alone $[67,104]$. In contrast to Lee et al., Chen et al. showed that combination therapy reduced tumor-infiltrating neutrophils [67]. They reported that VPN20009 alone attracted neutrophils to tumor site, but this recruitment was inhibited by the anti-inflammatory compound triptolide [67]. Interestingly, the preferential accumulation of Salmonella in tumor was further enhanced by the combination therapy in comparison to Salmonella 
alone $[67,102,104]$. This could be explained by the ability of the Salmonella-chemotherapy combination to reduce tumor microvascularization and provide a more hypoxic microenvironment that is conducive to Salmonella's colonization and proliferation $[67,104]$. Moreover, a study that utilized the combination of attenuated S. typhimurium and carboplatinum against metastatic cancer of unknown primary (CUP) reported the ability of the combination to significantly inhibit tumor growth compared to monotherapy treatment [105]. Table 1 shows a summary of representative studies that utilized Salmonella in combination with chemotherapeutic drugs to treat cancer.

Several potential mechanisms have been advanced to explain the demonstrably superior outcomes of Salmonella and chemotherapeutic agents in combination. Chang et al. showed that the anti-tumor effect of cisplatin was augmented when combined with Salmonella choleraesuis due to the capacity of Salmonella to increase the expression of connexin 43 (Cx43), therefore enhancing gap junction intercellular communication (GJIC) [106]. The expression of $\mathrm{C} \times 43$ is decreased in a variety of cancer cells and this may interfere with the response of tumor cells to treatments [107]. Salmonella overcomes this limitation by upregulating and activating the expression of $\mathrm{Cx} 43[78,106]$, thereby enhancing antigen presentation by dendritic cells [78] and facilitating the transmission of antitumor drugs and apoptosis signals between adjacent cancer cells [108]. Another study conducted by Yang et al. reported that Salmonella choleraesuis reduced the expression level of multi-drug resistance protein P-gp on tumor cells [59]. The decline in P-gp expression was accompanied by a decrease in its efflux capabilities and was attributed to the inhibition of p-AKT, p-p70S6K, and p-mTOR levels during Salmonella infection [59]. Given that high levels of P-gp on tumor cells are associated with chemotherapeutic drug resistance [109], the ability of Salmonella to regulate the expression of P-gp may enhance the sensitivity of tumor cells to chemotherapy. Chih's group demonstrated the ability of Salmonella choleraesuis to enhance the susceptibility of B16F10 and 4T1 cells to 5-fluorouracil therapy, as illustrated by the improved therapeutic effect of the combination in tumor-bearing mice [59]. It has been suggested that $S$. typhimurium could also improve the chemosensitivity of tumor cells by inducing the quiescent cancer cells from the $G_{0} / G_{1}$ phase to the $S / G_{2} / M$ phase in the cell cycle $[110,111]$. In one study, almost $90 \%$ of tumor cells in the center and $80 \%$ of the total cells in an established tumor were shown to be in $G_{0} / G_{1}$ phase of the cell cycle [112]. Given that cytotoxic agents are only effective in killing proliferating cancer cells with minimal effect on quiescent cancer cells [112], Salmonella could enhance the chemosensitivity of quiescent tumor cells by decoying them from a chemo-resistant $G_{0} / G_{1}$ phase to a chemo-sensitive $S / G_{2} / M$ phase. This combination improved the therapeutic efficacy of cisplatinum against the osteosarcoma PDOX lung metastasis model [45]. In this study, Salmonella strain A1-R was utilized to enhance the sensitivity and push quiescent tumor cells to $S / G_{2}$ phase, while recombinant methioninase was used to selectively trap the cells in this stage [45]. Finally, chemotherapy was administered to tumor-bearing mice, and this combination resulted in a remarkable tumor reduction compared to monotherapy and bitherapy [45]. In this context, the new paradigm in cancer therapy was referred to as "decoy, trap and shoot (kill)" chemotherapy [45,111]. 
Table 1. Representative pre-clinical examples of Salmonella-chemotherapy combination in treating cancer.

\begin{tabular}{|c|c|c|c|c|c|c|}
\hline $\begin{array}{c}\text { Chemotherapeutic } \\
\text { Agent }\end{array}$ & Salmonella Strain & $\begin{array}{l}\text { Route of Salmonella } \\
\text { Administration }\end{array}$ & $\begin{array}{l}\text { Cancer Model/ } \\
\text { Mouse Strain }\end{array}$ & Outcome of Combination Treatment & Associated Mechanism & Ref \\
\hline $\begin{array}{l}\text { CHOP chemotherapy (a } \\
\text { cyclophosphamide, } \\
\text { doxorubicin, vincristine, } \\
\text { and prednisone/steroid } \\
\text { combination) }\end{array}$ & $\begin{array}{l}\text { S. typhimurium } \\
\text { LVR01 }\end{array}$ & Intratumoral & $\begin{array}{l}\text { B-cell non-Hodgkin } \\
\text { lymphoma (murine A20 } \\
\text { cell line)/BALB/c mice }\end{array}$ & $\begin{array}{l}\text { Delayed tumor growth } \\
\text { compared to monotherapy alone } \\
\text { Prolonged overall survival and } \\
\text { progression-free survival of } \\
\text { tumor-bearing mice } \\
\text { - } \quad \begin{array}{l}\text { Improved overall health status } \\
\text { of mice undergoing } \\
\text { chemotherapy }\end{array}\end{array}$ & $\begin{array}{l}\text { - Increase in the \% of intratumoral } \mathrm{CD} 8^{+} \mathrm{T} \\
\text { cells } \\
\text { Increase in the infiltration of neutrophils } \\
\text { and NK cells in tumors (compared to } \\
\text { untreated and chemotherapy-receiving } \\
\text { mice) } \\
\text { - Enhanced NK cell-mediated cytotoxicity } \\
\text { Improved anti-A20 specific antibody } \\
\text { immune responses (compared to } \\
\text { untreated and chemotherapy-receiving } \\
\text { mice) } \\
\text { Upregulation in Cxcl1 gene expression }\end{array}$ & [100] \\
\hline Doxorubicin & $\begin{array}{l}\text { S. typhimurium } \\
\text { DSLpNG }\end{array}$ & Intravenous & $\begin{array}{c}\text { Autochthonous model of } \\
\text { breast } \\
\text { cancer/BALB/neuT mice }\end{array}$ & $\begin{array}{l}\text { - Inhibited tumor growth rate } \\
\text { more efficiently than Salmonella } \\
\text { alone or low-dose doxorubicin } \\
\text { alone } \\
\text { No clinically relevant toxicity } \\
\text { was reported in treated mice }\end{array}$ & $\begin{array}{l}\text { - Increase in the infiltration of } \mathrm{CD}^{+} \mathrm{T} \text { cells } \\
\text { and Treg cells in tumors } \\
\text { Increased Mo-MDSCs/G-MDSCs ratio } \\
\text { within spleen and tumor tissues (this } \\
\text { was observed in Salmonella-treated and } \\
\text { combination-treated groups, but not } \\
\text { among doxorubicin-receiving mice) }\end{array}$ & [101] \\
\hline Cisplatin & S. choleraesuis & Intraperitoneal & $\begin{array}{l}\text { Lung tumor } \\
\text { (murine LL/2 cell } \\
\text { line)/C57BL/6 mice } \\
\text { and hepatoma } \\
\text { (murine ML-1 cell } \\
\text { line)/BALB/c mice }\end{array}$ & $\begin{array}{l}\text { - Additively retarded tumor } \\
\text { growth in both highly aggressive } \\
\text { lung tumor and slowly growing } \\
\text { hepatoma models } \\
\text { Prolonged survival time }\end{array}$ & $\begin{array}{l}\text { - Combination therapy promoted the } \\
\text { preferential accumulation of Salmonella } \\
\text { within lung tumors } \\
\text { An increase in the number of infiltrating } \\
\text { CD8 }{ }^{+} \text {T cells, neutrophils, and apoptotic } \\
\text { cells was observed in tumor tissues }\end{array}$ & [102] \\
\hline Gemcitabine & $\begin{array}{l}\text { S. typhimurium } \\
\text { A1-R }\end{array}$ & Intravenous & $\begin{array}{l}\text { Pancreatic cancer PDOX } \\
\text { mouse model/nude mice }\end{array}$ & $\begin{array}{l}\text { - Inhibited tumor growth } \\
\text { compared to monotherapy } \\
\text { No effect on mice body weights } \\
\text { was observed }\end{array}$ & $\begin{array}{l}\text { Extensive necrosis was observed in } \\
\text { tumor tissues from } \\
\text { gemcitabine-Salmonella receiving mice in } \\
\text { comparison to untreated mice }\end{array}$ & [103] \\
\hline Cyclophosphamide & $\begin{array}{l}\text { S. typhimurium } \\
\text { VNP20009 }\end{array}$ & Intraperitoneal & $\begin{array}{l}\text { Melanoma model } \\
\text { (murine B16F10 cell } \\
\text { line)/C57BL/6 mice }\end{array}$ & $\begin{array}{l}\text { - } \quad \text { Remarkable tumor growth } \\
\text { inhibition was observed when } \\
\text { Salmonella was combined with } \\
\text { MTD and LDM chemotherapy } \\
\text { - } \quad \text { Prolonged overall survival }\end{array}$ & $\begin{array}{l}\text { - } \quad \text { Decrease in tumor microvessel density } \\
\text { - Increase in serum levels of VEGF } \\
\text { Increase in the number of bacteria within } \\
\text { tumors when compared with bacterial } \\
\text { treatment alone }\end{array}$ & [104] \\
\hline
\end{tabular}


Table 1. Cont.

\begin{tabular}{|c|c|c|c|c|c|c|}
\hline $\begin{array}{c}\text { Chemotherapeutic } \\
\text { Agent }\end{array}$ & Salmonella Strain & $\begin{array}{l}\text { Route of Salmonella } \\
\text { Administration }\end{array}$ & $\begin{array}{l}\text { Cancer Model/ } \\
\text { Mouse Strain }\end{array}$ & Outcome of Combination Treatment & Associated Mechanism & Ref \\
\hline Triptolide & $\begin{array}{l}\text { S. typhimurium } \\
\text { VNP20009 }\end{array}$ & $\begin{array}{l}\text { Intraperitoneal or } \\
\text { intratumoral }\end{array}$ & $\begin{array}{l}\text { Melanoma model } \\
\text { (murine B16F10 cell } \\
\text { line)/C57BL/6 mice }\end{array}$ & $\begin{array}{l}\text { - Suppressed melanoma tumor } \\
\text { growth (through both } \\
\text { intraperitoneal and intratumoral } \\
\text { routes of bacterial } \\
\text { administration) } \\
\text { Remarkably prolonged the } \\
\text { survival length of tumor-bearing } \\
\text { mice (through the } \\
\text { intraperitoneal injection of } \\
\text { Salmonella) }\end{array}$ & 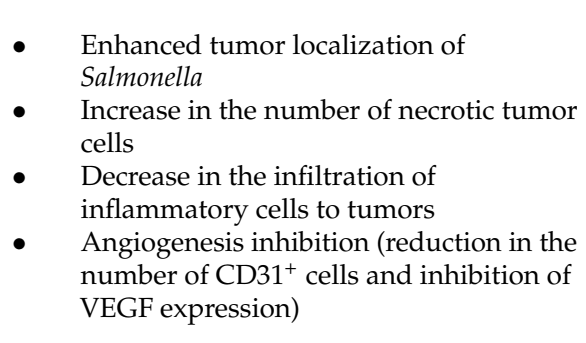 & [67] \\
\hline Carboplati-num & $\begin{array}{l}\text { S. typhimurium } \\
\text { A1-R }\end{array}$ & Intravenous & $\begin{array}{l}\text { Cancer of unknown } \\
\text { primary PDOX model/ } \\
\text { nude mice }\end{array}$ & $\begin{array}{l}\text { - Suppressed tumor growth } \\
\text { compared to each treatment } \\
\text { alone }\end{array}$ & $\begin{array}{l}\text { - } \quad \text { Reduced tumor cell size and cellularity } \\
\text { Extensive cytoplasmic vacuolization in } \\
\text { tumor cells was observed }\end{array}$ & [105] \\
\hline
\end{tabular}

(Mo-MDSCs: monocytic myeloid-derived suppressor cells; G-MDSCs: granulocytic myeloid-derived suppressor cells; MTD: maximum tolerated dose; LDM: low-dose metronomic). 


\subsection{Combination with Radiotherapy}

Radiotherapy is a conventional cancer treatment in which $\sim 50 \%$ of cancer patients receive radiation during the course of the disease [113]. However, radiotherapy-associated limitations obstruct achieving favorable therapeutic outcome without causing toxicity to normal tissues. Salmonella has been combined with radiotherapy aiming to enhance the overall efficacy of the treatment. In a study conducted in 2014, Yoon et al. utilized S. typhimurium to increase the radiosensitivity of the radio-resistant melanoma model [114]. They documented the success of Salmonella and gamma radiation combination and its ability to induce greater apoptosis in B16F10 cells in comparison to radiotherapy alone or Salmonella alone [114]. They also showed that the combinatorial treatment resulted in a significant inhibition of tumor growth in melanoma-bearing mice, and a prolonged survival rate compared to monotherapy [114]. Other groups performed studies in which engineered Salmonella was combined with radiotherapy. The combination of lipid A mutant S. typhimurium and X-rays resulted in a supra-additive therapeutic effect in B16F10 or Cloudman $S 91$ melanoma-bearing mice [115]. Other studies demonstrated an improved CT26 tumor growth inhibition when treated with a combination of S. typhimurium strain $\triangle \mathrm{ppGpp} / \mathrm{pBAD}-\mathrm{ClyA}$ and radiotherapy, highlighting the contribution of radiotherapy to the colonization of Salmonella in tumor tissues [116]. Chen et al. intended to improve specificity and anti-tumor therapeutic ability against malignant melanoma by taking advantage of the preferential colonization of Salmonella strain VNP20009 in the hypoxic tumor tissues and coating this bio-therapeutic agent with the photothermal agent polydopamine [117]. In this therapy, the systemic administration of Salmonella helped in the delivery of polydopamine to hypoxic and poorly vascularized regions of the tumor. Thereafter, when tumor tissue was irradiated, polydopamine helped in the conversion of near-infrared light into heat, which then increased the local temperature and eventually killed the surrounding cancerous cells, leading to tumor growth inhibition. The authors brought attention to the ability of this combination to substantially eliminate melanoma tumors without relapse [117]. The combinatorial therapy also resulted in a higher level of apoptosis in melanoma tumors and a greater induction of cytokine secretion, which contributed to the enhanced anti-tumor effect. Attenuated Salmonella typhi Ty21a was also an excellent vehicle to deliver gold nanoparticles to the radio-resistant central hypoxic regions of CT-26 colon cancer [118]. Gold nanoparticles have been shown to enhance the efficacy of radiotherapy [119]. Thereby, when these particles reach hypoxic regions, this compensates the low anti-tumor efficacy of radiotherapy at tumor hypoxic sites. From an immunological perspective, Salmonellainduced changes in the immune component of tumor microenvironment could underlie its ability to enhance tumor radiosensitivity. Barker et al. proposed various immunological mechanisms for radiosensitization, including: (a) increasing the number and activation levels of dendritic cells, (b) effective T-cell recruitment and activation, (c) inhibition of T-cell exhaustion and abrogation of inhibitory signaling, and (d) induction of specific cytokine (GM-CSF, IL-2 and IL-12) and chemokine (CCL3 and CCL5) release [120]. We have previously discussed the role of Salmonella in manipulating both innate and adaptive components of the immune system and highlighted its potential in immunomodulating the tumor niche. The capacity of Salmonella to transform the tumor microenvironment from being immunosuppressive to be immunogenic makes it a good candidate for improving the sensitivity of tumor to radiotherapy.

\subsection{Combination with Immune Checkpoint Inhibitors}

There is no doubt that the development of immune checkpoint inhibitors is considered a paramount achievement in cancer immunotherapy. Checkpoint inhibitors mainly work by targeting the negative regulators of T cell function, such as CTLA-4, PD-1, and PD-L1, unleashing T-cells and allowing them to induce tumor cell death. The past few years have witnessed unprecedented and promising therapeutic outcomes in different types of cancer, including advanced melanoma [121,122] and non-small cell lung carcinoma [123,124]. Despite the outstanding success reported with immune checkpoint inhibitors, the per- 
centage of cancer patients who respond to this approach remains rather modest [125], and serious immune-related adverse events were observed in some patients receiving checkpoint inhibitors therapy $[126,127]$. This observation has led to the identification of different predictive biomarkers that help in patient selection, such as (a) the presence of tumor-infiltrating lymphocytes [128-131], (b) the expression level of checkpoint inhibitors [132,133], and (c) the tumor mutational load [134,135].

Different studies have evaluated the effect of Salmonella on the expression of inhibitory checkpoint proteins in different tumor and non-tumor cells. Chen et al. reported that Salmonella choleraesuis dose-dependently downregulated the expression of PD-L1 on different murine and human cancer cell lines through inhibiting the AKT/mTOR/p70s6K signaling pathway [136]. They also showed that the systemic administration of Salmonella decreased the expression of PD-L1 in B16F10 and LL2 tumor tissues [136]. This downregulation enhanced $\mathrm{T}$ cell infiltration and thereby resulted in tumor growth inhibition [136]. Another study documented the role of attenuated shIDO-ST (S. typhimurium delivering an shRNA plasmid targeting IDO) in inhibiting the expression of several inhibitory checkpoint proteins, including PD-L1, PD-1, and CTLA4, in different splenic immune cells [137] which highlights the capacity of Salmonella to restructure the immune component of the tumor microenvironment in favor of tumor inhibition. On the other hand, different studies reported Salmonella-mediated upregulation of PD-L1 in different cell types. Newland et al. utilized transcriptome analysis and flowcytometry to study the effect of $S$. typhimurium on PD-L1 expression in NOD mice [138]. In their model, the intravenous administration of Salmonella significantly increased the proportion and surface expression of PD-L1 among dendritic cells and macrophages [138]. Others also reported an increase in PD-L1 expression in B cells and $\mathrm{CD} 4^{+} \mathrm{T}$ cells following Salmonella treatment [139-141]. It is worth mentioning that none of these studies correlated the increased PD-L1 expression with tumor growth inhibition.

Binder et al. elegantly demonstrated the capacity of ovalbumin-producing $S$. typhimurium A1-R and anti PD-L1 combination to rescue the function of peripheral and tumor infiltrating $\mathrm{CD} 8^{+} \mathrm{T}$ cells against B16-OVA melanoma [142]. This led to an increase in tumor rejection compared to bacterial therapy alone or the combination of anti PD-L1 and anti-CTLA-4 [142]. The same study reported the failure of Salmonella and anti CTLA-4 combination in treating tumor-bearing mice. Zhao et al. combined bacterial therapy with immune checkpoint inhibitors by transforming attenuated S. typhimurium with a plasmid for RNA interference targeting the inhibitory receptor PD-1 (siRNA-PD-1), and used it in B16 melanoma [143] and CT26 colon cancer [144] models. They reported a preferential accumulation of transformed Salmonella in tumor tissues [143] and found that the intratumoral injection of siRNA-PD-1-carrying Salmonella resulted in (a) a remarkable decrease in tumor weight, (b) prolonged survival rate of tumor bearing mice, in addition to (c) an increase in $\mathrm{CD}^{+}$and $\mathrm{CD}^{+}$TILs compared to treatment with Salmonella containing a plasmid for scrambled si-RNA $[143,144]$. It is worth noting that a comparison with anti-PD-1 alone was not performed. In another study of colon cancer, CT26 or MC38 tumor-bearing mice treated with a combination of Salmonella carrying IDO siRNA and anti-PD-1 showed delayed tumor growth in comparison to anti PD-1 monotherapy [145]. However, the combination showed no additional tumor growth inhibition compared to Salmonella treatment alone [145]. A recent study also used sub-therapeutic doses of IDO-targeting S. typhimurium along with anti-PD-1/CTLA-4 antibodies to treat LLC1-tumor bearing mice [137]. They observed a significant delay in tumor growth in mice that received the treatment combination in comparison to those received either treatment alone, and this inhibition was associated with an increase in tumor infiltration of $\mathrm{CD}^{+}$and $\mathrm{CD} 8^{+} \mathrm{T}$ cells [137]. These results collectively highlighted Salmonella's capacity to enhance the efficacy of checkpoint inhibitors in treating tumor-bearing mice. However, the immunological response underlying the enhanced outcome of Salmonella-checkpoint inhibitors combination did not receive sufficient attention and need to be further investigated. 


\subsection{Combination with Immunomodulatory Cytokines}

The approval of using immunomodulatory cytokines as a part of cancer therapeutics dates back to late 20th century, when IL-2 was approved by the USFDA for treatment of metastatic kidney cancer and metastatic melanoma [146] and IFN-alpha for hairy cell leukemia [147]. In Europe, TNF was licensed for treating irresectable soft tissue sarcoma. Nowadays, these cytokines are no longer used in clinical applications due to the severe toxicities associated with their systemic administration and their limited effectiveness [3,148]. Salmonella's ability to specifically target tumor tissues and the fact that it can be easily genetically modified raised the notion of utilizing Salmonella as a vector to carry immunomodulatory agents to tumor tissues and express them under a controlled expression system. For example, the oral administration of S. typhimurium expressing human IL-2 was successful in enhancing the anti-tumor effects and reducing the number of metastasis in mice with unresectable hepatic malignancies [87]. It was also shown that $\mathrm{CD} 8^{+} \mathrm{T}$ cells and NK cells were responsible for the antitumor activity [149]. This was also shown in other studies that utilized Salmonella carrying IL-2 gene for the treatment of murine osteosarcoma [150] and melanoma [56]. In a canine osteosarcoma model, Salmonella expressing IL-2 resulted in a prolonged disease-free interval [151]. In patients with metastatic gastrointestinal cancer, attenuated Salmonella carrying IL-2 resulted in an increase in circulating NK and NKT cells but with no survival advantage [152]. In the B16F10 melanoma model, subcutaneous administration of $S$. typhimurium expressing IFN- $\gamma$ resulted in efficient tumor inhibition and prolonged survival mainly driven by the NK cell response [153]. S. typhimurium harboring TNF- $\alpha$ also showed potential against murine melanoma, with an ability to enhance the outcome of other cancer therapeutics [154]. In a study conducted by Loeffler et al., Salmonella expressing the chemokine CCL21 significantly inhibited the growth of multi-drug resistant murine carcinomas in a CD4 ${ }^{-}$and $\mathrm{CD}^{-}$cell-dependent manner. This inhibition was associated with elevated levels of IFN- $\gamma$, CXCL9 and CXCL10 [155]. Several other studies [156-159] utilized different cytokine-expressing bacteria and emphasized the remarkable potential of Salmonella to deliver immunomodulators in an efficient and well-tolerated manner.

\subsection{Combination with Other Therapies}

Along with the previously mentioned promising approaches, Salmonella could be also combined with other therapies, including adoptive T cell transfer [160], anti-angiogenesis therapy [161], caffeine and valproic acid [162], and a traditional Chinese medicine herbal mixture [163], to improve anti-tumor effects. An interesting study demonstrated that $\mathrm{T}$ cell transfer in combination with either the intravenous administration of live bacteria or intratumoral treatment with heat-killed bacteria resulted in long-established tumor eradication and relapse prevention, thereby improving the outcome of adoptive $T$ cell transfer [160]. It is worth noting that this enhanced outcome was driven by the increased number of neutrophils and decreased number of monocytes in the tumor microenvironment [160], which have been thought to enhance T cell therapeutic efficacy [164]. In another study, significant tumor growth inhibition was observed when $S$. typhimurium A1-R was utilized in combination with caffeine and valproic acid against pleomorphic rhabdomyosarcoma PDOX model, and this inhibition was greater than that observed with cyclophosphamide treatment [162]. Moreover, the combination of S. typhimurium and traditional Chinese medicine herbal mixture also showed potential in treating aggressive types of cancer compared to monotherapies [163].

\section{Clinical Application of Salmonella in Combination Cancer Therapy}

\subsection{Clinical Trials}

Several genera of bacteria have been studied in pre-clinical settings, and a few bacterial platforms have been selected for testing in human patients, namely Listeria monocytogenes, Clostridium novyi, and S. typhimurium. These bacterial species have received the most attention due to the increased understanding of their physiology, pathogenicity, and genetics which, in turn, led to the development of attenuation strategies critical for safe 
administration of live bacteria in humans. Among bacterial species tested in clinical settings, strains of Listeria monocytogenes have shown encouraging and promising results [21]. Besides, clinical signs of tumor colonization and objective evidence of tumor responses have been observed following the intravenous and intratumoral administration of Clostridium novyi-NT spores [165-167]. The observed tumor destruction and absence of viable tumor cells were attributed to gas pockets produced by Clostridium novyi-NT. However, treatment with oncolytic bacteria alone failed to eradicate all cancer cells, and thereby led to tumor progression or recurrence $[166,168]$.

The first Salmonella strain studied in human clinical trials was S. typhimurium VNP20009, and was tested against metastatic melanoma and metastatic renal carcinoma. The study revealed that the maximum tolerated dose was $3.0 \times 10^{8} \mathrm{CFU} / \mathrm{m}^{2}$ injected through the intravenous route. Despite the observed tumor colonization and increased pro-inflammatory cytokines in some of the treated patients, no objective tumor regression was reported [169]. Another clinical trial utilized S. typhimurium VNP20009 to treat metastatic melanoma patients. Consistent with previous findings, no tumor regression was documented among treated patients [170]. In order to improve therapeutic efficacy, VNP20009 was engineered to express the $E$ coli CD enzyme, which converts the non-toxic 5-FC into anti-tumor 5-FU, and was tested in three patients with head and neck squamous carcinoma and esophageal adenocarcinoma through intratumoral injection. Tumor colonization was observed in two patients for at least 15 days post administration, with a 3:1 tumor-to-plasma ratio of 5-FU; this ratio was $<1.0$ in the non-colonized patient. No adverse effects were reported following the treatment [171]. Later trials utilized the oral route for Salmonella administration. S. typhimurium Ty21a that expresses VEGFR2 (VXM01 vaccine) has been used against advanced pancreatic cancer. Although the engineered bacteria succeeded in enhancing VEGFR2-specific T cell effector responses and reducing tumor perfusion, adverse events such as neutrophilia, lymphopenia, and diarrhea were observed in treated subjects [172]. SalpIL2 (S. typhimurium that expresses human IL-2) showed no significant benefits in phase I clinical study against metastatic gastrointestinal cancer. On the other hand, an increase in circulating NK cells and NK-T cells was reported among treated patients [152], which provides insights into the possibility of combining Salmonella strains with other approaches of cancer immunotherapy. Table 2 summarizes previous and ongoing clinical trials using Salmonella-based cancer therapy. The results of clinical trials highlighted the discrepancy in the therapeutic outcome between pre-clinical and clinical models. This could be related to differences in tumor contextures and growth rates that might alter bacterial invasiveness and proliferation within tumor tissues [173]. Others attributed the inefficiency of BMCT in clinical trials to the over-attenuation of the utilized bacteria which, in turn, compromises its anti-tumor effects [174]. 
Table 2. Summary of previous and ongoing bacterial-therapy clinical trials utilizing Salmonella.

\begin{tabular}{|c|c|c|c|c|c|c|}
\hline Salmonella Strain & $\begin{array}{c}\text { Route of } \\
\text { Administration }\end{array}$ & Cancer Model & Phase & Recruitment Status & $\begin{array}{c}\text { Identifier } \\
\text { (Nct Number) }\end{array}$ & Ref \\
\hline VNP20009 & Intratumoral & Refractory, superficial solid tumors & I & Completed & NCT00004216 & [175] \\
\hline VNP20009 & Intravenous & Advanced or metastatic cancer & I & Completed & NCT00004988 & [176] \\
\hline VNP20009 & Intravenous & $\begin{array}{l}\text { Metastatic melanoma and metastatic } \\
\text { renal cell carcinoma (RCC) }\end{array}$ & I & Completed & NCT00006254 & [177] \\
\hline $\begin{array}{l}\text { S. typhimurium SalpIL2 } \\
\text { (expresses human IL-2) }\end{array}$ & Oral & Liver metastasis of solid tumors & I & Completed & NCT01099631 & [178] \\
\hline $\begin{array}{l}\text { VXM01 vaccine } \\
\text { (S. typhimurium Ty21a expresses VEGFR2) }\end{array}$ & Oral & Advanced pancreatic cancer & I & Completed & NCT01486329 & [179] \\
\hline $\begin{array}{l}\text { Salmonella CVD908ssb strain } \\
\text { (TXSVN vaccine) }\end{array}$ & Oral & Multiple myeloma & I & Not yet recruiting & NCT03762291 & [180] \\
\hline $\begin{array}{l}\text { S. typhimurium strain (SS2017) expressing } \\
\text { tumor DNA vaccine }\end{array}$ & Oral & Neuroblastoma & Early phase I & Recruiting & NCT04049864 & [181] \\
\hline $\begin{array}{l}\text { Saltikva } \\
\text { (S. typhimurium expresses human IL-2) }\end{array}$ & Oral & Metastatic pancreatic cancer & II & Recruiting & NCT04589234 & [182] \\
\hline
\end{tabular}




\subsection{Challenges}

Despite the success reported with the use of Salmonella as an integral part of combination therapies, the translation of this success from pre-clinical to human clinical application still poses major challenges. The limitations associated with the clinical application of combinatorial therapies mirror those related to the implementation of Salmonella therapy alone. Although BMCT dates back to the mid-19th century, the introduction of Salmonella to human cancer treatment remains pending due to several challenges, including:

- Clinical safety. Bacterial pathogens can cause diseases through the action of virulence factors. On the other hand, the attenuation of virulence factors has been correlated with decreased anti-tumor therapeutic effects $[183,184]$. The optimized balance between reduced virulence and clinical efficacy remains the major challenge in the clinical application of BMCT. Moreover, not all bacterial strains that showed success in preclinical models can be used in clinical settings due to their distinct pathologies that differ in animals and humans.

- Route of administration. The systemic administration of bacteria increases the risk of toxicity and potential adverse effects of the infection. The oral administration is considered relatively safer but at the expense of therapeutic efficacy.

- Dose optimization. Since live bacteria proliferate in target tissues, the effective dose does not necessarily mirror the administered dose. The effective dose is dependent on different factors including the route of administration, accessibility to target tissues, level of vascularization, tumor immunogenicity, and the presence of tumor-infiltrating inflammatory cells [21].

- Genetic instability. Live genetically engineered bacteria that carry antibiotic resistance genes or mobile genetic elements are not suitable for clinical use since these recombinant elements can mediate horizontal gene transfer [185]. Other recombinant plasmids can be lost or mutated before reaching tumor tissues, leading to exaggerated infection or therapeutic failure [186].

- Bacterial growth control in vivo. The timely elimination of bacteria using an antibiotic intervention is critical since the early administration of antibiotic may eliminate the infection before an anti-tumor effect has been achieved, whereas a late intervention would result in unpredictable systemic inflammatory response. Microbiota disturbance and the development of antibiotic resistance should be kept in mind when using antibiotics to manage bacterial growth.

- Tumor recurrence. Despite the considerable role of bacteria in treating cancer, subsequent tumor recurrence could still be possible [14]. This may be attributed to the activation of immune tolerance or evasion mechanisms that interfere with the bacteria-mediated immune response [25].

- Patient selection. Chemotherapeutic agents suppress the immune system and interfere with delivering the immunomodulatory effects induced by BMCT. Therefore, the risk of bacterial infection is substantially increased in chemotherapy-receiving patients. In addition, brain abscesses, diverticulitis, or recent radiation might enhance the unintentional growth of bacteria in non-target tissues. Live bacteria also have the potential to colonize the foreign bodies in patients with joint replacement, artificial heart valves, and impanated medical devices [22]. Pre-exposure and anti-bacterial immunity should be also taken into account since they might interfere with the anti-tumor immune-stimulatory effects of the bacteria and result in treatment failure.

\subsection{Efforts to Overcome Challenges}

Salmonella's anti-cancer and immunomodulatory characteristics, along with its durable capacity to enhance the outcome of other modalities of cancer therapy, necessitate the development of strategies to overcome the limitations and facilitate the implementation of Salmonella in clinical use. In the past decades, several strategies have been followed to maintain the balance of therapeutic efficacy and safety when utilizing Salmonella in cancer therapy. The aim of the earliest approaches was to enhance tumor targeting by selection, 
and this was done by passaging Salmonella through cancer cells either in vitro or in vivo. The attenuated Salmonella strains VNP20009 and A1-R were generated following such strategy of random selection [187-189]. The ineffectiveness of VNP20009 in treating cancer patients was due to the over-attenuation through uncontrolled introduction of multiple deletions during the process of selection $[169,174]$. Salmonella strain A1-R showed promise in treating different types of cancer in pre-clinical models but has not been utilized in clinical trials so far $[187,190]$. Unexpected modifications were then avoided by designing Salmonella strains through targeted gene deletions. Frahm et al. and his group investigated the role of LPS in establishing the balance between the therapeutic and harmful effects of S. typhimurium. They concluded that minor modifications of LPS (e.g., $\Delta r f a P, \Delta r f a L$ ) alone did not alter the toxicity of Salmonella, whereas the core deletion mutants $\Delta r f a G$ and $\Delta r f a D$ considerably enhanced their safety at the expense of the anti-tumor activity [184]. To this point, they succeeded in establishing a balance between therapeutic potency and attenuation through controlling the synthesis of LPS using the inducible arabinose promoter $\mathrm{P}_{\mathrm{BAD}}[8,184]$. Targeted gene engineering was also implemented to induce modifications in Lipid A and flagella synthesis, resulting in the auxotrophic Salmonella vector strain SF200 ( $\triangle l p x R 9 \Delta p a g L 7 \triangle p a g P 8 \triangle a r o A \Delta y d i V \Delta f l i F)[191]$. This attenuated strain showed enhanced immune-stimulatory capacity and overcame the limitation of pre-exposure of anti-Salmonella immunity. The careful selection of genetic manipulations is critical for maintaining the balance between therapeutic potential and pathogenicity. Moreover, another study suggested an approach to override the non-specific invasiveness and intrinsic toxicity of Salmonella through coupling the bacteria with a surface-expressed single-domain antibody directed against a tumor-associated antigen [92]. This approach showed success when CD20-targeted Salmonella was employed against lymphomas with minimal nonspecific invasiveness [92]. Other researchers utilized Salmonella as a vector system for drug delivery in order to enhance its therapeutic potential and overcome the limitation in tumors that could not be resolved by the intrinsic and immunostimulatory effects of Salmonella alone. Interestingly, Din et al. illustrated the potential of utilizing Salmonella as a targeted delivery system for therapeutic agents. In their model, bacterial growth was controlled through engineering a bacterium that undergoes lysis at a threshold population density, allowing the repetitive release of genetically encoded anti-tumor therapeutic agents during lytic cycles [192]. This helps in delivering the therapeutic benefit while minimizing the systemic inflammatory response [192]. In this context, it would be ideal if bacterial presence could be controlled, allowing sufficient time to achieve the optimal anti-tumor effects and then eliminating it to avoid uncontrolled proliferation that may lead to unpredictable systemic inflammatory responses. Another innovative step in designing therapeutic vectors was taken by Mercado-Lubo et al. through conjugating gold nanoparticles (AuNPs) with the effector protein SipA of Salmonella SPI1 (Salmonella pathogenicity island 1) [193]. SipA protein induces caspase-3-mediated cleavage of the multi-drug resistance p-gp and inhibits its function. Despite the observation that the SipA-AuNPs nanoparticle did not result in any therapeutic effects when tested in murine tumor models of colon and breast cancers, the enhanced anti-tumor efficacy was observed when combined with doxorubicin. The therapeutic benefit was delivered by the capacity of the SipA protein to abrogate the function of $\mathrm{p}$-gp and therefore retrieve the desired effect of doxorubicin. The concept of applying nanoparticles to deliver Salmonella proteins is well-accepted in circumventing the safety concern of using infectious agent like Salmonella, but nanoparticles lack the unique feature of Salmonella in the preferential colonization of tumor tissues. A recently published paper utilized nanoparticle technology and Salmonella to enhance the treatment efficacy and safety [194]. They employed silver nanoparticles (AgNPs) conjugated with sialic acid to locally deplete tumor-infiltrating neutrophils through the selective recognition of L-selectin, thereby enhancing the efficacy of Salmonella. AgNPs also exert their function through inducing direct tumor cell killing and clearing Salmonella following tumor eradication to minimize the undesirable side effects. This way, the combination of Salmonella-AgNPs resulted in a superior therapeutic outcome. Furthermore, controling gene expression, 
either remotely or through the incorporation of gene promoters responsive to tumorassociated antigens, has shown a good potential in minimizing toxicity to normal tissues (discussed in Section 2.5).

In combinatorial therapies that involve bacterial treatment, high doses of bacteria are not necessarily correlated with a better outcome. Bacteria can be utilized at a low dose that is capable to induce changes in the immune components of the tumor microenvironment without any significant tumor inhibition effect. This way, it may enhance the therapeutic outcome and increase the efficacy of other treatments while keeping toxicity to minimal. As previously mentioned, the therapeutic index of bacterial therapy in pre-clinical model has been enhanced over the past few years with the designation of engineered bacteria. While retaining tumor specificity and anti-tumor efficacy, bacteria have been engineered for the purpose of (a) improving safety, (b) enhancing tumor targeting and minimizing toxicity to normal tissues, and (c) delivering various anti-tumor therapeutic agents such as cytokines, cytotoxic agents, tumor-associated antigens, and prodrug enzymes [21]. Taken all together, the durable success achieved with combination therapies (as compared to monotherapies) in pre-clinical models has increased the demand to overcome the challenges associated with bacterial therapy. This, in turn, will pave the way for implementing combination therapies involving Salmonella in clinical use.

\section{Conclusions}

The present review highlights the unique characteristics of Salmonella as a potential anti-cancer therapeutic agent. The essential tumor targeting capacity, adequate tumor tissue penetration, immunomodulatory effects, and extensive gene packaging capacity, in addition to efficacy in delivering anti-tumor therapeutic agents, suggest Salmonella as a good candidate for combination therapy in cancer. Several pre-clinical studies have demonstrated the enhanced anti-tumor efficacy of conventional and non-conventional cancer therapeutics in combination with attenuated Salmonella in different tumor models. The improved therapeutic outcome was shown in terms of tumor growth retardation, metastasis inhibition, and increased survival rate. Taking everything into consideration, the synergistic effect of combinatorial therapy is thought to be achieved through the ability of Salmonella to (a) improve the delivery and enhance specificity of cancer therapeutic agents to tumor site, (b) increase the antigenicity of tumor cells, and (c) manipulate the immune components of the tumor microenvironment to make it more conducive for improving other therapies, along with its ability to (d) minimize the toxicity associated with other cancer therapies either directly or indirectly by reducing the number of treatment cycles or prolonging the effect of a single treatment (Figure 3).

Although the potential of utilizing Salmonella to enhance the outcome of other therapies has been investigated, the mechanistic details underlying combination therapies are still scarce. Additional research is needed to expand the current findings and study the underlying mechanism(s) by which Salmonella improves the therapeutic outcome. Moreover, the modulation of the immune system in combination cancer therapy is worthy of further study because of its essential involvement in cancer development and progression. The increased understanding of the involvement of Salmonella in combinatorial therapies will facilitate the clinical translation of such an approach, thereby potentially ushering in a breakthrough in cancer therapy. 


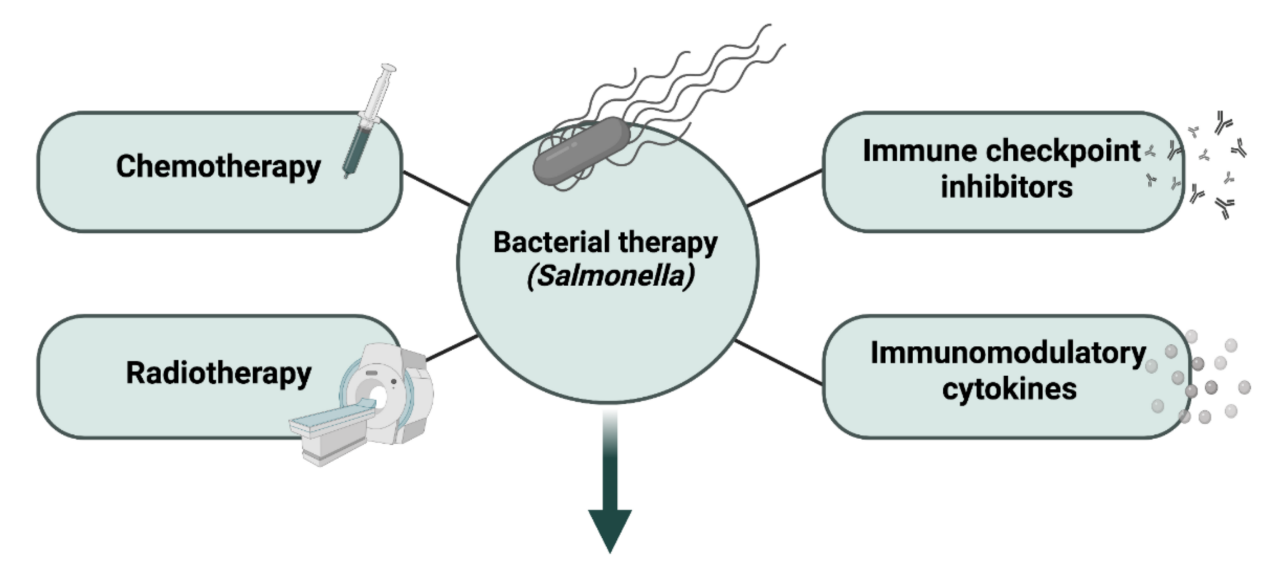

Increased anti-tumor efficacy and improved therapeutic outcome

(Enhanced tumor growth inhibition and overall survival rate)

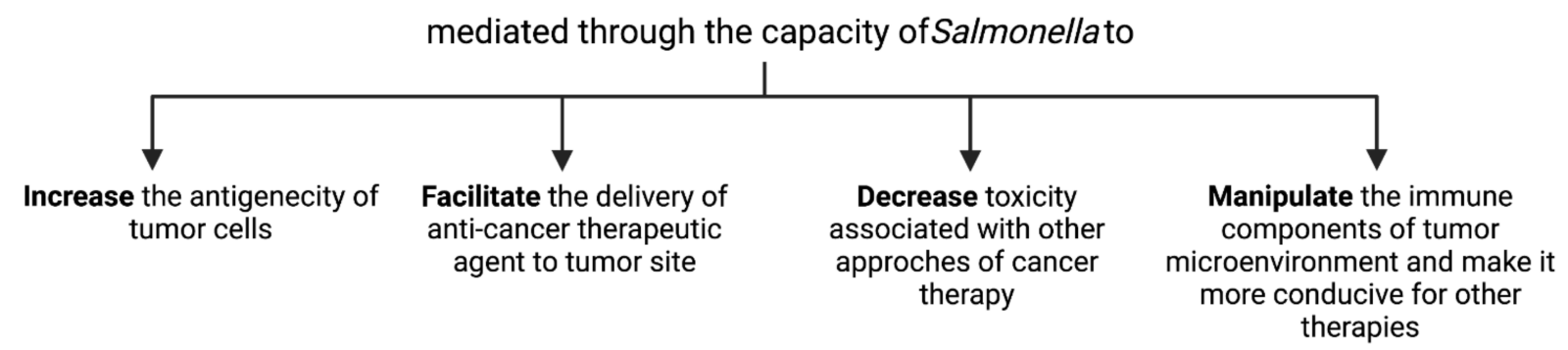

Figure 3. Combination treatments involving Salmonella in cancer. The administration of Salmonella was successful in improving therapeutic outcome of other conventional and non-conventional cancer treatments.

Author Contributions: Conceptualization-B.K.a.-R. and B.H.A.-S.; Investigation- B.H.A.-S.; Visualization-B.H.A.-S. and B.K.a.-R.; Writing-original draft, B.H.A.-S.; Writing-review and editing-B.H.A.-S., M.J.F.-C. and B.K.a.-R.; Supervision-M.J.F.-C. and B.K.a.-R.; Project Administration-B.K.a.-R.; Funding acquisition-B.K.a.-R. All authors have read and agreed to the published version of the manuscript.

Funding: Work in Dr Al-Ramadi's laboratory is supported by grants from the Terry Fox Foundation (\#I1030), the Sheikh Hamdan Award for Medical Sciences (MRG/107/2018), the Zayed Center for Health Sciences (\#31R088 and \#31R189), the UAEU Program for Advanced Research (\#31M193), and the Research Grants Committee (\#NP-15-02), College of Medicine and Health Sciences, United Arab Emirates University (to B.K.a.-R).

Acknowledgments: The authors wish to acknowledge United Arab Emirates University, the Shiekh Hamdan Award for Medical Sciences, and the Terry Fox Foundation for supporting this project. B.H.A.-S. is supported by a student scholarship from the Office of Graduate Studies, College of Medicine and Health Sciences, United Arab Emirates University (Al Ain, United Arab Emirates).

Conflicts of Interest: The authors declare no conflict of interest.
Abbreviations
CAR-T Chimeric antigen receptor $\mathrm{T}$ cell therapies
BMCT Bacterial-mediated cancer therapy
TNF- $\alpha$ Tumor necrosis factor-alpha
PDOX Patient-derived orthotopic xenograft
VEGF Vascular endothelial growth factor
p-gp P-glycoprotein
MMP-9 Matrix metalloproteinase 9 


$\begin{array}{ll}\text { Tregs } & \text { Regulatory T cells } \\ \text { iNOS } & \text { Inducible nitric oxide synthase } \\ \text { MDSCs } & \text { Myeloid-derived suppressor cells } \\ \text { IDO } & \text { Indoleamine 2,3-dioxygenase } \\ \text { NK } & \text { Natural killer } \\ \text { Cx43 } & \text { Connexin } 43 \\ \text { TILs } & \text { Tumor-infiltrating lymphocytes }\end{array}$

\section{References}

1. Cancer. Available online: https://www.who.int/news-room/fact-sheets/detail/cancer (accessed on 7 June 2021).

2. Yang, Y. Cancer immunotherapy: Harnessing the immune system to battle cancer. J. Clin. Investig. 2015, 125, 3335-3337. [CrossRef] [PubMed]

3. Zhao, Z.; Zheng, L.; Chen, W.; Weng, W.; Song, J.; Ji, J. Delivery strategies of cancer immunotherapy: Recent advances and future perspectives. J. Hematol. Oncol. 2019, 12, 1-14. [CrossRef] [PubMed]

4. Barbe, S.; Van Mellaert, L.; Anné, J. The use of clostridial spores for cancer treatment. J. Appl. Microbiol. 2006, 101, 571-578. [CrossRef] [PubMed]

5. Coley, W.B. Contribution to the Knowledge of Sarcoma. Ann. Surg. 1891, 14, 199-220. [CrossRef] [PubMed]

6. Coley, W.B. The treatment of malignant tumors by repeated inoculations of erysipelas. With a report of ten original cases. 1893. Clin. Orthop. Relat. Res. 1991, 262, 3-11.

7. Kocijancic, D.; Felgner, S.; Frahm, M.; Komoll, R.-M.; Iljazovic, A.; Pawar, V.; Rohde, M.; Heise, U.; Zimmermann, K.; Gunzer, F.; et al. Therapy of solid tumors using probiotic Symbioflor-2—restraints and potential. Oncotarget 2016, 7, 22605-22622. [CrossRef] [PubMed]

8. Felgner, S.; Kocijancic, D.; Frahm, M.; Curtiss, R.; Erhardt, M.; Weiss, S. Optimizing Salmonella entericaserovar Typhimurium for bacteria-mediated tumor therapy. Gut Microbes 2016, 7, 171-177. [CrossRef] [PubMed]

9. Kubiak, A.; Minton, N.P. The potential of clostridial spores as therapeutic delivery vehicles in tumour therapy. Res. Microbiol. 2015, 166, 244-254. [CrossRef]

10. Paterson, Y.; Guirnalda, P.D.; Wood, L.M. Listeria and Salmonella bacterial vectors of tumor-associated antigens for cancer immunotherapy. Semin. Immunol. 2010, 22, 183-189. [CrossRef]

11. Redelman-Sidi, G.; Glickman, M.S.; Bochner, B.H. The mechanism of action of BCG therapy for bladder cancer-A current perspective. Nat. Rev. Urol. 2014, 11, 153-162. [CrossRef]

12. Ganai, S.; Arenas, R.B.; Sauer, J.P.; Bentley, B.; Forbes, N.S. In tumors Salmonella migrate away from vasculature toward the transition zone and induce apoptosis. Cancer Gene Ther. 2011, 18, 457-466. [CrossRef]

13. Lee, C.-H.; Lin, S.-T.; Liu, J.-J.; Chang, W.-W.; Hsieh, J.-L.; Wang, W.-K. Salmonella induce autophagy in melanoma by the downregulation of AKT/mTOR pathway. Gene Ther. 2014, 21, 309-316. [CrossRef]

14. Kim, J.-E.; Phan, T.X.; Nguyen, V.H.; Dinh-Vu, H.-V.; Zheng, J.H.; Yun, M.; Park, S.-G.; Hong, Y.; Choy, H.E.; Szardenings, M.; et al. Salmonella typhimurium Suppresses Tumor Growth via the Pro-Inflammatory Cytokine Interleukin-1 $\beta$. Theranostics 2015, 5, 1328-1342. [CrossRef]

15. Sznol, M.; Lin, S.L.; Bermudes, D.; Zheng, L.-M.; King, I. Use of preferentially replicating bacteria for the treatment of cancer. J. Clin. Investig. 2000, 105, 1027-1030. [CrossRef]

16. Lee, C.-H.; Wu, C.-L.; Shiau, A.-L. Toll-like Receptor 4 Mediates an Antitumor Host Response Induced by Salmonella choleraesuis. Clin. Cancer Res. 2008, 14, 1905-1912. [CrossRef]

17. Grille, S.; Moreno, M.; Bascuas, T.; Marqués, J.M.; Muñoz, N.; Lens, D.; Chabalgoity, J.A. Salmonella entericaserovar Typhimurium immunotherapy for B-cell lymphoma induces broad anti-tumour immunity with therapeutic effect. Immunology 2014, 143, 428-437. [CrossRef]

18. Lee, C.-H.; Hsieh, J.-L.; Wu, C.-L.; Hsu, P.-Y.; Shiau, A.-L. T cell augments the antitumor activity of tumor-targeting Salmonella. Appl. Microbiol. Biotechnol. 2011, 90, 1381-1388. [CrossRef]

19. Clairmont, C.; Lee, K.C.; Pike, J.; Ittensohn, M.; Low, K.B.; Pawelek, J.; Bermudes, D.; Brecher, S.M.; Margitich, D.; Turnier, J.; et al. Biodistribution and Genetic Stability of the Novel Antitumor Agent VNP20009, a Genetically Modified Strain of Salmonella typhimurium. J. Infect. Dis. 2000, 181, 1996-2002. [CrossRef]

20. Liang, K.; Liu, Q.; Li, P.; Luo, H.; Wang, H.; Kong, Q. Genetically engineered Salmonella Typhimurium: Recent advances in cancer therapy. Cancer Lett. 2019, 448, 168-181. [CrossRef]

21. Zhou, S.; Gravekamp, C.; Bermudes, D.; Liu, K. Tumour-targeting bacteria engineered to fight cancer. Nat. Rev. Cancer 2018, 18, 727-743. [CrossRef]

22. Dróżdż, M.; Makuch, S.; Cieniuch, G.; Woźniak, M.; Ziółkowski, P. Obligate and facultative anaerobic bacteria in targeted cancer therapy: Current strategies and clinical applications. Life Sci. 2020, 261, 118296. [CrossRef] [PubMed]

23. Mi, Z.; Feng, Z.-C.; Li, C.; Yang, X.; Ma, M.-T.; Rong, P.-F. Salmonella-Mediated Cancer Therapy: An Innovative Therapeutic Strategy. J. Cancer 2019, 10, 4765-4776. [CrossRef] [PubMed]

24. Wang, D.; Wei, X.; Kalvakolanu, D.V.; Guo, B.; Zhang, L. Perspectives on Oncolytic Salmonella in Cancer Immunotherapy-A Promising Strategy. Front. Immunol. 2021, 12, 615930. [CrossRef] 
25. Guo, Y.; Chen, Y.; Liu, X.; Min, J.-J.; Tan, W.; Zheng, J.H. Targeted cancer immunotherapy with genetically engineered oncolytic Salmonella typhimurium. Cancer Lett. 2020, 469, 102-110. [CrossRef] [PubMed]

26. Al-Ramadi, B.K.; Fernandez-Cabezudo, M.J.; El-Hasasna, H.; Al-Salam, S.; Attoub, S.; Xu, D.; Chouaib, S. Attenuated Bacteria as Effectors in Cancer Immunotherapy. Ann. N. Y. Acad. Sci. 2008, 1138, 351-357. [CrossRef] [PubMed]

27. Yu, Y.A.; Zhang, Q.; Szalay, A.A. Establishment and characterization of conditions required for tumor colonization by intravenously delivered bacteria. Biotechnol. Bioeng. 2008, 100, 567-578. [CrossRef] [PubMed]

28. Kasinskas, R.W.; Forbes, N.S. Salmonella typhimurium specifically chemotax and proliferate in heterogeneous tumor tissue in vitro. Biotechnol. Bioeng. 2006, 94, 710-721. [CrossRef]

29. Kasinskas, R.W.; Forbes, N.S. Salmonella typhimurium Lacking Ribose Chemoreceptors Localize in Tumor Quiescence and Induce Apoptosis. Cancer Res. 2007, 67, 3201-3209. [CrossRef]

30. Anderson, C.J.; Clark, D.E.; Adli, M.; Kendall, M.M. Ethanolamine Signaling Promotes Salmonella Niche Recognition and Adaptation during Infection. PLoS Pathog. 2015, 11, e1005278. [CrossRef]

31. Silva-Valenzuela, C.A.; Desai, P.T.; Molina-Quiroz, R.C.; Pezoa, D.; Zhang, Y.; Porwollik, S.; Zhao, M.; Hoffman, R.M.; Contreras, I.; Santiviago, C.A.; et al. Solid tumors provide niche-specific conditions that lead to preferential growth of Salmonella. Oncotarget 2016, 7, 35169-35180. [CrossRef]

32. Toley, B.; Forbes, N.S. Motility is critical for effective distribution and accumulation of bacteria in tumor tissue. Integr. Biol. 2012, 4, 165-176. [CrossRef]

33. Stritzker, J.; Weibel, S.; Seubert, C.; Götz, A.; Tresch, A.; van Rooijen, N.; Oelschlaeger, T.A.; Hill, P.; Gentschev, I.; Szalay, A.A. Enterobacterial tumor colonization in mice depends on bacterial metabolism and macrophages but is independent of chemotaxis and motility. Int. J. Med. Microbiol. 2010, 300, 449-456. [CrossRef]

34. Leschner, S.; Westphal, K.; Dietrich, N.; Viegas, N.; Jablonska, J.; Lyszkiewicz, M.; Lienenklaus, S.; Falk, W.; Gekara, N.O.; Loessner, $\mathrm{H}$; et al. Tumor Invasion of Salmonella enterica Serovar Typhimurium Is Accompanied by Strong Hemorrhage Promoted by TNF- $\alpha$. PLOS ONE 2009, 4, e6692. [CrossRef]

35. Wang, H.; Chen, T.; Wan, L.; Lu, J.; Wei, H.; Deng, K.-Y.; Wei, J.; Xin, H.-B. Attenuated Salmonella engineered with an apoptosisinducing factor (AIF) eukaryotic expressing system enhances its anti-tumor effect in melanoma in vitro and in vivo. Appl. Microbiol. Biotechnol. 2020, 104, 3517-3528. [CrossRef]

36. Kaimala, S.; Mohamed, Y.A.; Nader, N.; Issac, J.; Elkord, E.; Chouaib, S.; Fernandez-Cabezudo, M.J.; Al-Ramadi, B.K. Salmonellamediated tumor regression involves targeting of tumor myeloid suppressor cells causing a shift to M1-like phenotype and reduction in suppressive capacity. Cancer Immunol. Immunother. 2014, 63, 587-599. [CrossRef]

37. Murakami, T.; Hiroshima, Y.; Zhao, M.; Zhang, Y.; Chishima, T.; Tanaka, K.; Bouvet, M.; Endo, I.; Hoffman, R.M. Therapeutic efficacy of tumor-targeting Salmonella typhimuriumA1-R on human colorectal cancer liver metastasis in orthotopic nude-mouse models. Oncotarget 2015, 6, 31368-31377. [CrossRef]

38. Zhao, C.; He, J.; Cheng, H.; Zhu, Z.; Xu, H. Enhanced therapeutic effect of an antiangiogenesis peptide on lung cancer in vivo combined with Salmonella VNP20009 carrying a Sox2 shRNA construct. J. Exp. Clin. Cancer Res. 2016, 35, 107. [CrossRef]

39. Choe, E.; Kazmierczak, R.A.; Eisenstark, A. Phenotypic Evolution of Therapeutic Salmonella enterica Serovar Typhimurium after Invasion of TRAMP Mouse Prostate Tumor. mBio 2014, 5, e01182-14. [CrossRef]

40. Hiroshima, Y.; Zhang, Y.; Zhao, M.; Zhang, N.; Murakami, T.; Maawy, A.; Mii, S.; Uehara, F.; Yamamoto, M.; Miwa, S.; et al. Tumor-Targeting Salmonella typhimurium A1-R in Combination with Trastuzumab Eradicates HER-2-Positive Cervical Cancer Cells in Patient-Derived Mouse Models. PLoS ONE 2015, 10, e0120358. [CrossRef]

41. Vendrell, A.; Gravisaco, M.J.; Goin, J.C.; Pasetti, M.F.; Herschllik, L.; De Toro, J.; Rodríguez, C.; Larotonda, G.; Mongini, C.; Waldner, C.I. Therapeutic Effects of Salmonella Typhi in a Mouse Model of T-Cell Lymphoma. J. Immunother. 2013, 36, 171-180. [CrossRef]

42. Miwa, S.; Yano, S.; Zhang, Y.; Matsumoto, Y.; Uehara, F.; Yamamoto, M.; Hiroshima, Y.; Kimura, H.; Hayashi, K.; Yamamoto, N.; et al. Tumor-targeting Salmonella typhimurium A1-R prevents experimental human breast cancer bone metastasis in nude mice. Oncotarget 2014, 5, 7119-7125. [CrossRef]

43. Hayashi, K.; Zhao, M.; Yamauchi, K.; Yamamoto, N.; Tsuchiya, H.; Tomita, K.; Kishimoto, H.; Bouvet, M.; Hoffman, R.M. Systemic targeting of primary bone tumor and lung metastasis of high-grade osteosarcoma in nude mice with a tumor-selective strain of Salmonella typhymurium. Cell Cycle 2009, 8, 870-875. [CrossRef]

44. Kimura, H.; Zhang, L.; Zhao, M.; Hayashi, K.; Tsuchiya, H.; Tomita, K.; Bouvet, M.; Wessels, J.; Hoffman, R.M. Targeted therapy of spinal cord glioma with a genetically modified Salmonella typhimurium. Cell Prolif. 2010, 43, 41-48. [CrossRef]

45. Igarashi, K.; Kawaguchi, K.; Kiyuna, T.; Miyake, K.; Miyake, M.; Li, S.; Han, Q.; Tan, Y.; Zhao, M.; Li, Y.; et al. Tumor-targeting Salmonella typhimurium A1-R combined with recombinant methioninase and cisplatinum eradicates an osteosarcoma cisplatinumresistant lung metastasis in a patient-derived orthotopic xenograft (PDOX) mouse model: Decoy, trap and kill chemotherapy moves toward the clinic. Cell Cycle 2018, 17, 801-809. [CrossRef]

46. Hoffman, R.M. Patient-Derived Orthotopic Xenograft (PDOX) Models of Melanoma. Int. J. Mol. Sci. 2017, 18, 1875. [CrossRef]

47. Murakami, T.; Delong, J.; Eilber, F.C.; Zhao, M.; Zhang, Y.; Zhang, N.; Singh, A.; Russell, T.; Deng, S.; Reynoso, J.; et al. Tumortargeting Salmonella typhimurium A1-R in combination with doxorubicin eradicate soft tissue sarcoma in a patient-derived orthotopic xenograft (PDOX) model. Oncotarget 2016, 7, 12783-12790. [CrossRef] 
48. Kiyuna, T.; Murakami, T.; Tome, Y.; Kawaguchi, K.; Igarashi, K.; Zhang, Y.; Zhao, M.; Li, Y.; Bouvet, M.; Kanaya, F.; et al. High efficacy of tumor-targeting Salmonella typhimurium A1-R on a doxorubicin- and dactolisib-resistant follicular dendritic-cell sarcoma in a patient-derived orthotopic xenograft PDOX nude mouse model. Oncotarget 2016, 7, 33046-33054. [CrossRef]

49. Li, C.-X.; Yu, B.; Shi, L.; Geng, W.; Lin, Q.-B.; Ling, C.-C.; Yang, M.; Ng, K.T.P.; Huang, J.-D.; Man, K. 'Obligate' anaerobic Salmonella strain YB1 suppresses liver tumor growth and metastasis in nude mice. Oncol. Lett. 2016, 13, 177-183. [CrossRef]

50. Li, B.; He, H.; Zhang, S.; Zhao, W.; Li, N.; Shao, R. Salmonella typhimurium strain SL7207 induces apoptosis and inhibits the growth of HepG2 hepatoma cells In vitro and in vivo. Acta Pharm. Sin. B 2012, 2, 562-568. [CrossRef]

51. Eisenstark, A.; Kazmierczak, R.A.; Dino, A.; Khreis, R.; Newman, D.; Schatten, H. Development of Salmonella Strains as Cancer Therapy Agents and Testing in Tumor Cell Lines. In Methods in Molecular Biology; Springer Science and Business Media LLC: Berlin, Germany, 2007; Volume 394, pp. 323-354.

52. Forbes, N.S. Engineering the perfect (bacterial) cancer therapy. Nat. Rev. Cancer 2010, 10, 785-794. [CrossRef]

53. Liu, B.; Jiang, Y.; Dong, T.; Zhao, M.; Wu, J.; Li, L.; Chu, Y.; She, S.; Zhao, H.; Hoffman, R.M.; et al. Blockage of autophagy pathway enhances Salmonella tumor-targeting. Oncotarget 2016, 7, 22873-22882. [CrossRef] [PubMed]

54. Tu, D.-G.; Chang, W.-W.; Lin, S.-T.; Kuo, C.-Y.; Tsao, Y.-T.; Lee, C.-H. Salmonella inhibits tumor angiogenesis by downregulation of vascular endothelial growth factor. Oncotarget 2016, 7, 37513-37523. [CrossRef] [PubMed]

55. Liu, F.; Zhang, L.; Hoffman, R.M.; Zhao, M. Vessel destruction by tumor-targeting Salmonella typhimuriumA1-R is enhanced by high tumor vascularity. Cell Cycle 2010, 9, 4518-4524. [CrossRef] [PubMed]

56. Al-Ramadi, B.K.; Fernandez-Cabezudo, M.J.; El-Hasasna, H.; Al-Salam, S.; Bashir, G.; Chouaib, S. Potent anti-tumor activity of systemically-administered IL2-expressing Salmonella correlates with decreased angiogenesis and enhanced tumor apoptosis. Clin. Immunol. 2009, 130, 89-97. [CrossRef]

57. Spector, M.P.; Del Portillo, F.G.; Bearson, S.M.D.; Mahmud, A.; Magut, M.; Finlay, B.B.; Dougan, G.; Foster, J.W.; Pallen, M.J. The rpoS-dependent starvation-stress response locus stiA encodes a nitrate reductase (narZYWV) required for carbon-starvationinducible thermotolerance and acid tolerance in Salmonella typhimurium. Microbiology 1999, 145, 3035-3045. [CrossRef]

58. Barak, Y.; Schreiber, F.; Thorne, S.H.; Contag, C.H.; De Beer, D.; Matin, A.C. Role of nitric oxide in Salmonella typhimuriummediated cancer cell killing. BMC Cancer 2010, 10, 146. [CrossRef]

59. Yang, C.-J.; Chang, W.-W.; Lin, S.-T.; Chen, M.-C.; Lee, C.-H. Salmonella Overcomes Drug Resistance in Tumor through Pglycoprotein Downregulation. Int. J. Med. Sci. 2018, 15, 574-579. [CrossRef]

60. Tsao, Y.-T.; Kuo, C.-Y.; Cheng, S.-P.; Lee, C.-H. Downregulations of AKT/mTOR Signaling Pathway for Salmonella-Mediated Suppression of Matrix Metalloproteinases-9 Expression in Mouse Tumor Models. Int. J. Mol. Sci. 2018, 19, 1630. [CrossRef]

61. Kaimala, S.; Al-Sbiei, A.; Marques, O.C.; Fernandez-Cabezudo, M.J.; Al-Ramadi, B.K. Attenuated Bacteria as Immunotherapeutic Tools for Cancer Treatment. Front. Oncol. 2018, 8, 136. [CrossRef]

62. Lee, C.-H.; Hsieh, J.-L.; Wu, C.-L.; Hsu, H.-C.; Shiau, A.-L. B cells are required for tumor-targeting Salmonella in host. Appl. Microbiol. Biotechnol. 2011, 92, 1251-1260. [CrossRef]

63. Zheng, J.H.; Nguyen, V.H.; Jiang, S.-N.; Park, S.-H.; Tan, W.; Hong, S.H.; Shin, M.G.; Chung, I.-J.; Hong, Y.; Bom, H.-S.; et al. Two-step enhanced cancer immunotherapy with engineered Salmonella typhimuriumsecreting heterologous flagellin. Sci. Transl. Med. 2017, 9, eaak9537. [CrossRef]

64. Granot, Z. Neutrophils as a Therapeutic Target in Cancer. Front. Immunol. 2019, 10, 1710. [CrossRef]

65. Cai, Z.; Sanchez, A.; Shi, Z.; Zhang, T.; Liu, M.; Zhang, D. Activation of Toll-like Receptor 5 on Breast Cancer Cells by Flagellin Suppresses Cell Proliferation and Tumor Growth. Cancer Res. 2011, 71, 2466-2475. [CrossRef]

66. Liu, T.; Chopra, A.K. An enteric pathogen Salmonella enterica serovar Typhimurium suppresses tumor growth by downregulating CD44high and CD4T regulatory (Treg) cell expression in mice: The critical role of lipopolysaccharide and Braun lipoprotein in modulating tumor growth. Cancer Gene Ther. 2009, 17, 97-108. [CrossRef]

67. Chen, J.; Qiao, Y.; Tang, B.; Chen, G.; Liu, X.; Yang, B.; Wei, J.; Zhang, X.; Cheng, X.; Du, P.; et al. Modulation of Salmonella Tumor-Colonization and Intratumoral Anti-angiogenesis by Triptolide and Its Mechanism. Theranostics 2017, 7, $2250-2260$. [CrossRef]

68. Johannessen, M.; Askarian, F.; Sangvik, M.; Sollid, J.E. Bacterial interference with canonical NFkB signalling. Microbiology 2013, 159, 2001-2013. [CrossRef]

69. Simon, R.; Samuel, C.E. Activation of NF-кB-dependent gene expression by Salmonella flagellins FliC and FljB. Biochem. Biophys. Res. Commun. 2007, 355, 280-285. [CrossRef]

70. Souvannavong, V.; Saidji, N.; Chaby, R. Lipopolysaccharide from Salmonella enterica Activates NF-kB through both Classical and Alternative Pathways in Primary B Lymphocytes. Infect. Immun. 2007, 75, 4998-5003. [CrossRef]

71. Janeway, C.A., Jr.; Medzhitov, R. Innate immune recognition. Annu. Rev. Immunol. 2002, 20, 197-216. [CrossRef]

72. Kocijancic, D.; Felgner, S.; Schauer, T.; Frahm, M.; Heise, U.; Zimmermann, K.; Erhardt, M.; Weiss, S. Local application of bacteria improves safety of Salmonella-mediated tumor therapy and retains advantages of systemic infection. Oncotarget 2017, 8, 49988-50001. [CrossRef]

73. Na, H.S.; Kim, H.J.; Lee, H.C.; Hong, Y.; Rhee, J.H.; Choy, H.E. Immune response induced by Salmonella typhimurium defective in ppGpp synthesis. Vaccine 2006, 24, 2027-2034. [CrossRef]

74. Hernández-Luna, M.A.; Luria-Pérez, R. Cancer Immunotherapy: Priming the Host Immune Response with Live Attenuated Salmonella enterica. J. Immunol. Res. 2018, 2018, 1-15. [CrossRef] 
75. Chang, S.-Y.; Kim, Y.-J.; Ko, H.-J. Potential therapeutic anti-tumor effect of a Salmonella-based vaccine. Hum. Vaccines Immunother. 2013, 9, 1654-1660. [CrossRef]

76. Kocijancic, D.; Leschner, S.; Felgner, S.; Komoll, R.-M.; Frahm, M.; Pawar, V.; Weiss, S. Therapeutic benefit of Salmonella attributed to LPS and TNF- $\alpha$ is exhaustible and dictated by tumor susceptibility. Oncotarget 2017, 8, 36492-36508. [CrossRef]

77. Phan, T.X.; Nguyen, V.H.; Duong, M.T.-Q.; Hong, Y.; Choy, H.E.; Min, J.-J. Activation of inflammasome by attenuated Salmonella typhimuriumin bacteria-mediated cancer therapy. Microbiol. Immunol. 2015, 59, 664-675. [CrossRef]

78. Saccheri, F.; Pozzi, C.; Avogadri, F.; Barozzi, S.; Faretta, M.; Fusi, P.; Rescigno, M. Bacteria-Induced Gap Junctions in Tumors Favor Antigen Cross-Presentation and Antitumor Immunity. Sci. Transl. Med. 2010, 2, 44ra57. [CrossRef]

79. Abel, A.M.; Yang, C.; Thakar, M.S.; Malarkannan, S. Natural Killer Cells: Development, Maturation, and Clinical Utilization. Front. Immunol. 2018, 9, 1869. [CrossRef]

80. Kuan, Y.-D.; Lee, C.-H. Salmonella overcomes tumor immune tolerance by inhibition of tumor indoleamine 2, 3-dioxygenase 1 expression. Oncotarget 2015, 7, 374-385. [CrossRef]

81. Wang, W.-K.; Lu, M.-F.; Kuan, Y.-D.; Lee, C.-H. The treatment of mouse colorectal cancer by oral delivery tumor-targeting Salmonella. Am. J. Cancer Res. 2015, 5, 2222-2228.

82. Fallarino, F.; Grohmann, U.; Puccetti, P. Indoleamine 2,3-dioxygenase: From catalyst to signaling function. Eur. J. Immunol. 2012, 42, 1932-1937. [CrossRef]

83. Low, K.B.; Ittensohn, M.; Le, T.; Platt, J.; Sodi, S.; Amoss, M.; Ash, O.; Carmichael, E.; Chakraborty, A.; Fischer, J.; et al. Lipid A mutant Salmonella with suppressed virulence and TNF $\alpha$ induction retain tumor-targeting in vivo. Nat. Biotechnol. 1999, 17, 37-41. [CrossRef] [PubMed]

84. Hoffman, R.M. Tumor-seeking Salmonella amino acid auxotrophs. Curr. Opin. Biotechnol. 2011, 22, 917-923. [CrossRef] [PubMed]

85. Zhao, M.; Geller, J.; Ma, H.; Yang, M.; Penman, S.; Hoffman, R.M. Monotherapy with a tumor-targeting mutant of Salmonella typhimurium cures orthotopic metastatic mouse models of human prostate cancer. Proc. Natl. Acad. Sci. USA 2007, 104, 10170-10174. [CrossRef]

86. Zhao, M.; Yang, M.; Li, X.-M.; Jiang, P.; Baranov, E.; Li, S.; Xu, M.; Penman, S.; Hoffman, R.M. Tumor-targeting bacterial therapy with amino acid auxotrophs of GFP-expressing Salmonella typhimurium. Proc. Natl. Acad. Sci. USA 2005, 102, 755-760. [CrossRef] [PubMed]

87. Saltzman, D.A.; Heise, C.P.; Hasz, D.E.; Zebede, M.; Kelly, S.M.; Curtiss, R.; Leonard, A.S.; Anderson, P.M. Attenuated Salmonella typhimuriumContaining Interleukin-2 Decreases MC-38 Hepatic Metastases: A Novel Anti-tumor Agent. Cancer Biotherapy Radiopharm. 1996, 11, 145-153. [CrossRef] [PubMed]

88. Mesa-Pereira, B.; Medina, C.; Camacho, E.; Flores, A.; Santero, E. Improved cytotoxic effects of Salmonella-producing cytosine deaminase in tumour cells. Microb. Biotechnol. 2014, 8, 169-176. [CrossRef]

89. King, I.; Bermudes, D.; Lin, S.; Belcourt, M.; Pike, J.; Troy, K.; Le, T.; Ittensohn, M.; Mao, J.; Lang, W.; et al. Tumor-Targeted Salmonella Expressing Cytosine Deaminase as an Anticancer Agent. Hum. Gene Ther. 2002, 13, 1225-1233. [CrossRef]

90. Bystander Effect Caused by Cytosine Deaminase Gene and 5-Fluorocytosine In vitro Is Substantially Mediated by Generated 5-Fluorouracil-PubMed. Available online: https:/ / pubmed.ncbi.nlm.nih.gov/9858915/ (accessed on 15 June 2021).

91. Bereta, M.; Hayhurst, A.; Gajda, M.; Chorobik, P.; Targosz, M.; Marcinkiewicz, J.; Kaufman, H.L. Improving tumor targeting and therapeutic potential of Salmonella VNP20009 by displaying cell surface CEA-specific antibodies. Vaccine 2007, 25, 4183-4192 [CrossRef]

92. Massa, P.E.; Paniccia, A.; Monegal, A.; De Marco, A.; Rescigno, M. Salmonella engineered to express CD20-targeting antibodies and a drug-converting enzyme can eradicate human lymphomas. Blood 2013, 122, 705-714. [CrossRef]

93. Mengesha, A.; Dubois, L.; Lambin, P.; Landuyt, W.; Chiu, R.K.; Wouters, B.G.; Theys, J. Development of a flexible and potent hypoxia-inducible promoter for tumor-targeted gene expression in attenuated Salmonella. Cancer Biol. Ther. 2006, 5, 1120-1128. [CrossRef]

94. Yang, Y.-W.; Zhang, C.-M.; Huang, X.-J.; Zhang, X.-X.; Zhang, L.-K.; Li, J.-H.; Hua, Z.-C. Tumor-targeted delivery of a C-terminally truncated FADD (N-FADD) significantly suppresses the B16F10 melanoma via enhancing apoptosis. Sci. Rep. 2016, 6, srep34178. [CrossRef]

95. Al-Ramadi, B.K.; Adeghate, E.; Mustafa, N.; Ponery, A.S.; Fernandez-Cabezudo, M.J. Cytokine expression by attenuated intracellular bacteria regulates the immune response to infection: The Salmonella model. Mol. Immunol. 2002, 38, 931-940. [CrossRef]

96. Loessner, H.; Endmann, A.; Leschner, S.; Westphal, K.; Rohde, M.; Miloud, T.; Hämmerling, G.; Neuhaus, K.; Weiss, S. Remote control of tumour-targeted Salmonella enterica serovar Typhimurium by the use of l-arabinose as inducer of bacterial gene expression in vivo. Cell. Microbiol. 2007, 9, 1529-1537. [CrossRef]

97. Royo, J.L.; Becker, P.D.; Camacho, E.M.; Cebolla, Á.; Link, C.; Santero, E.; Guzmán, C. in vivo gene regulation in Salmonella spp. by a salicylate-dependent control circuit. Nat. Chem. Biol. 2007, 4, 937-942. [CrossRef]

98. Kim, K.; Jeong, J.H.; Lim, D.; Hong, Y.; Lim, H.J.; Kim, G.J.; Shin, S.R.; Lee, J.J.; Yun, M.; Harris, R.A.; et al. L-Asparaginase delivered by Salmonella typhimurium suppresses solid tumors. Mol. Ther. Oncolytics 2015, 2, 15007. [CrossRef]

99. Jiang, S.-N.; Park, S.-H.; Lee, H.J.; Zheng, J.H.; Kim, H.-S.; Bom, H.-S.; Hong, Y.; Szardenings, M.; Shin, M.G.; Kim, S.-C.; et al. Engineering of Bacteria for the Visualization of Targeted Delivery of a Cytolytic Anticancer Agent. Mol. Ther. 2013, 21, $1985-1995$. [CrossRef] 
100. Bascuas, T.; Moreno, M.; Grille, S.; Chabalgoity, J.A. Salmonella Immunotherapy Improves the Outcome of CHOP Chemotherapy in Non-Hodgkin Lymphoma-Bearing Mice. Front. Immunol. 2018, 9, 23. [CrossRef]

101. Saltzman, D.; Augustin, L.; Leonard, A.; Mertensotto, M.; Schottel, J. Low dose chemotherapy combined with attenuated Salmonella decreases tumor burden and is less toxic than high dose chemotherapy in an autochthonous murine model of breast cancer. Surgery 2018, 163, 509-514. [CrossRef]

102. Lee, C.-H.; Wu, C.-L.; Tai, Y.-S.; Shiau, A.-L. Systemic administration of attenuated Salmonella choleraesuis in combination with cisplatin for cancer therapy. Mol. Ther. 2005, 11, 707-716. [CrossRef]

103. Kawaguchi, K.; Miyake, K.; Zhao, M.; Kiyuna, T.; Igarashi, K.; Miyake, M.; Higuchi, T.; Oshiro, H.; Bouvet, M.; Unno, M.; et al. Tumor targeting Salmonella typhimurium A1-R in combination with gemcitabine (GEM) regresses partially GEM-resistant pancreatic cancer patient-derived orthotopic xenograft (PDOX) nude mouse models. Cell Cycle 2018, 17, 2019-2026. [CrossRef]

104. Jia, L.-J.; Wei, D.-P.; Sun, Q.-M.; Jin, G.-H.; Li, S.-F.; Huang, Y.; Hua, Z.-C. Tumor-targeting Salmonella typhimurium improves cyclophosphamide chemotherapy at maximum tolerated dose and low-dose metronomic regimens in a murine melanoma model. Int. J. Cancer 2007, 121, 666-674. [CrossRef] [PubMed]

105. Miyake, K.; Kiyuna, T.; Miyake, M.; Zhao, M.; Wangsiricharoen, S.; Kawaguchi, K.; Zhang, Z.; Higuchi, T.; Razmjooei, S.; Li, Y.; et al. Tumor-targeting Salmonella typhimurium A1-R overcomes partial carboplatinum-resistance of a cancer of unknown primary (CUP). Tissue Cell 2018, 54, 144-149. [CrossRef] [PubMed]

106. Chang, W.-W.; Lai, C.-H.; Chen, M.-C.; Liu, C.-F.; Kuan, Y.-D.; Lin, S.-T.; Lee, C.-H. Salmonella enhance chemosensitivity in tumor through connexin 43 upregulation. Int. J. Cancer 2013, 133, 1926-1935. [CrossRef] [PubMed]

107. Wang, M.; Berthoud, V.M.; Beyer, E.C. Connexin43 increases the sensitivity of prostate cancer cells to TNF $\alpha$-induced apoptosis. J. Cell Sci. 2007, 120, 320-329. [CrossRef]

108. Mancuso, M.; Pasquali, E.; Leonardi, S.; Rebessi, S.; Tanori, M.; Giardullo, P.; Borra, F.; Pazzaglia, S.; Naus, C.C.; Di Majo, V.; et al. Role of connexin43 and ATP in long-range bystander radiation damage and oncogenesis in vivo. Oncogene 2011, 30, 4601-4608. [CrossRef]

109. Nanayakkara, A.K.; Follit, C.A.; Chen, G.; Williams, N.S.; Vogel, P.D.; Wise, J.G. Targeted inhibitors of P-glycoprotein increase chemotherapeutic-induced mortality of multidrug resistant tumor cells. Sci. Rep. 2018, 8, 1-18. [CrossRef]

110. Yano, S.; Zhang, Y.; Zhao, M.; Hiroshima, Y.; Miwa, S.; Uehara, F.; Kishimoto, H.; Tazawa, H.; Bouvet, M.; Fujiwara, T.; et al. Tumor-targeting Salmonella typhimurium A1-R decoys quiescent cancer cells to cycle as visualized by FUCCI imaging and become sensitive to chemotherapy. Cell Cycle 2014, 13, 3958-3963. [CrossRef]

111. Yano, S.; Takehara, K.; Zhao, M.; Tan, Y.; Han, Q.; Li, S.; Bouvet, M.; Fujiwara, T.; Hoffman, R.M. Tumor-specific cell-cycle decoy by Salmonella typhimurium A1-R combined with tumor-selective cell-cycle trap by methioninase overcome tumor intrinsic chemoresistance as visualized by FUCCI imaging. Cell Cycle 2016, 15, 1715-1723. [CrossRef]

112. Yano, S.; Zhang, Y.; Miwa, S.; Tome, Y.; Hiroshima, Y.; Uehara, F.; Yamamoto, M.; Suetsugu, A.; Kishimoto, H.; Tazawa, H.; et al. Spatial-temporal FUCCI imaging of each cell in a tumor demonstrates locational dependence of cell cycle dynamics and chemoresponsiveness. Cell Cycle 2014, 13, 2110-2119. [CrossRef]

113. Delaney, G.; Jacob, S.; Featherstone, C.; Barton, M. The role of radiotherapy in cancer treatment: Estimating optimal utilization from a review of evidence-based clinical guidelines. Cancer 2005, 104, 1129-1137. [CrossRef]

114. Yoon, W.S.; Kim, S.; Seo, S.; Park, Y. Salmonella typhimurium with $\gamma$-radiation induced H2AX phosphorylation and apoptosis in melanoma. Biosci. Biotechnol. Biochem. 2014, 78, 1082-1085. [CrossRef]

115. Platt, J.; Sodi, S.; Kelley, M.; Rockwell, S.; Bermudes, D.; Low, K.; Pawelek, J. Antitumour effects of genetically engineered Salmonella in combination with radiation. Eur. J. Cancer 2000, 36, 2397-2402. [CrossRef]

116. Liu, X.; Jiang, S.; Piao, L.; Yuan, F. Radiotherapy combined with an engineered Salmonella typhimurium inhibits tumor growth in a mouse model of colon cancer. Exp. Anim. 2016, 65, 413-418. [CrossRef]

117. Chen, W.; Wang, Y.; Qin, M.; Zhang, X.; Zhang, Z.; Sun, X.; Gu, Z. Bacteria-Driven Hypoxia Targeting for Combined Biotherapy and Photothermal Therapy. ACS Nano 2018, 12, 5995-6005. [CrossRef]

118. Kefayat, A.; Ghahremani, F.; Motaghi, H.; Rostami, S.; Mehrgardi, M.A. Alive attenuated Salmonella as a cargo shuttle for smart carrying of gold nanoparticles to tumour hypoxic regions. J. Drug Target. 2019, 27, 315-324. [CrossRef]

119. Cui, L.; Her, S.; Borst, G.R.; Bristow, R.; Jaffray, D.; Allen, C. Radiosensitization by gold nanoparticles: Will they ever make it to the clinic? Radiother. Oncol. 2017, 124, 344-356. [CrossRef]

120. Barker, H.E.; Paget, J.T.E.; Khan, A.; Harrington, K. The tumour microenvironment after radiotherapy: Mechanisms of resistance and recurrence. Nat. Rev. Cancer 2015, 15, 409-425. [CrossRef]

121. Hodi, F.S.; O’Day, S.J.; McDermott, D.F.; Weber, R.W.; Sosman, J.A.; Haanen, J.B.; Gonzalez, R.; Robert, C.; Schadendorf, D.; Hassel, J.C.; et al. Improved Survival with Ipilimumab in Patients with Metastatic Melanoma. N. Engl. J. Med. 2010, 363, 711-723. [CrossRef]

122. Robert, C.; Thomas, L.; Bondarenko, I.; O’Day, S.; Weber, J.; Garbe, C.; Lebbe, C.; Baurain, J.-F.; Testori, A.; Grob, J.-J.; et al. Ipilimumab plus Dacarbazine for Previously Untreated Metastatic Melanoma. N. Engl. J. Med. 2011, 364, 2517-2526. [CrossRef]

123. Brahmer, J.; Reckamp, K.L.; Baas, P.; Crinò, L.; Eberhardt, W.E.; Poddubskaya, E.; Antonia, S.; Pluzanski, A.; Vokes, E.E.; Holgado, E.; et al. Nivolumab versus Docetaxel in Advanced Squamous-Cell Non-Small-Cell Lung Cancer. N. Engl. J. Med. 2015, 373, 123-135. [CrossRef] 
124. Garon, E.B.; Rizvi, N.A.; Hui, R.; Leighl, N.; Balmanoukian, A.S.; Eder, J.P.; Patnaik, A.; Aggarwal, C.; Gubens, M.; Horn, L.; et al. Pembrolizumab for the Treatment of Non-Small-Cell Lung Cancer. N. Engl. J. Med. 2015, 372, 2018-2028. [CrossRef]

125. Darvin, P.; Toor, S.M.; Nair, V.S.; Elkord, E. Immune checkpoint inhibitors: Recent progress and potential biomarkers. Exp. Mol. Med. 2018, 50,1-11. [CrossRef]

126. Wang, D.Y.; Salem, J.-E.; Cohen, J.V.; Chandra, S.; Menzer, C.; Ye, F.; Zhao, S.; Das, S.; Beckermann, K.E.; Ha, L.; et al. Fatal Toxic Effects Associated With Immune Checkpoint Inhibitors: A Systematic Review and Meta-Analysis. JAMA Oncol. 2018, 4, 1721-1728. [CrossRef]

127. Feng, Y.; Roy, A.; Masson, E.; Chen, T.-T.; Humphrey, R.; Weber, J.S. Exposure-Response Relationships of the Efficacy and Safety of Ipilimumab in Patients with Advanced Melanoma. Clin. Cancer Res. 2013, 19, 3977-3986. [CrossRef]

128. Cogdill, A.P.; Andrews, M.C.; Wargo, J.A. Hallmarks of response to immune checkpoint blockade. Br. J. Cancer 2017, 117, 1-7. [CrossRef]

129. Pagès, F.; Berger, A.; Camus, M.; Sanchez-Cabo, F.; Costes, A.; Molidor, R.; Mlecnik, B.; Kirilovsky, A.; Nilsson, M.; Damotte, D.; et al. Effector Memory T Cells, Early Metastasis, and Survival in Colorectal Cancer. N. Engl. J. Med. 2005, 353, 2654-2666. [CrossRef]

130. De Angulo, G.; Yuen, C.; Ms, S.L.P.; Anderson, P.M.; Zweidler-McKay, P.A. Absolute lymphocyte count is a novel prognostic indicator in ALL and AML: Implications for Risk Stratification and Future Studies. Cancer 2007, 112, 407-415. [CrossRef]

131. Simeone, E.; Gentilcore, G.; Giannarelli, D.; Grimaldi, A.; Caracò, C.; Curvietto, M.; Esposito, A.; Paone, M.; Palla, M.; Cavalcanti, E.; et al. Immunological and biological changes during ipilimumab treatment and their potential correlation with clinical response and survival in patients with advanced melanoma. Cancer Immunol. Immunother. 2014, 63, 675-683. [CrossRef]

132. Teng, M.W.L.; Ngiow, S.F.; Ribas, A.; Smyth, M.J. Classifying Cancers Based on T-cell Infiltration and PD-L1. Cancer Res. 2015, 75, 2139-2145. [CrossRef]

133. Reck, M.; Rodríguez-Abreu, D.; Robinson, A.G.; Hui, R.; Csőszi, T.; Fülöp, A.; Gottfried, M.; Peled, N.; Tafreshi, A.; Cuffe, S.; et al. Pembrolizumab versus Chemotherapy for PD-L1-Positive Non-Small-Cell Lung Cancer. N. Engl. J. Med. 2016, 375, 1823-1833. [CrossRef]

134. Snyder, A.; Makarov, V.; Merghoub, T.; Yuan, J.; Zaretsky, J.M.; Desrichard, A.; Walsh, L.A.; Postow, M.A.; Wong, P.; Ho, T.S.; et al. Genetic Basis for Clinical Response to CTLA-4 Blockade in Melanoma. N. Engl. J. Med. 2014, 371, 2189-2199. [CrossRef] [PubMed]

135. Rizvi, N.A.; Hellmann, M.D.; Snyder, A.; Kvistborg, P.; Makarov, V.; Havel, J.J.; Lee, W.; Yuan, J.; Wong, P.; Ho, T.S.; et al. Mutational landscape determines sensitivity to PD-1 blockade in non-small cell lung cancer. Science 2015, 348, 124-128. [CrossRef] [PubMed]

136. Chen, M.-C.; Pangilinan, C.R.; Lee, C.-H. Salmonella Breaks Tumor Immune Tolerance by Downregulating Tumor Programmed Death-Ligand 1 Expression. Cancers 2019, 12, 57. [CrossRef] [PubMed]

137. Ebelt, N.D.; Zuniga, E.; Marzagalli, M.; Zamloot, V.; Blazar, B.R.; Salgia, R.; Manuel, E.R. Salmonella-Based Therapy Targeting Indoleamine 2,3-Dioxygenase Restructures the Immune Contexture to Improve Checkpoint Blockade Efficacy. Biomedicines 2020, 8, 617. [CrossRef]

138. Newland, S.A.; Phillips, J.M.; Mastroeni, P.; Azuma, M.; Zaccone, P.; Cooke, A. PD-L1 blockade overrides Salmonella typhimuriummediated diabetes prevention in NOD mice: No role for Tregs. Eur. J. Immunol. 2011, 41, 2966-2976. [CrossRef]

139. Lopez-Medina, M.; Perez-Lopez, A.; Alpuche-Aranda, C.; Ortiz-Navarrete, V.; Cunningham, A.; Round, J. Salmonella Modulates B Cell Biology to Evade CD8 + T Cell-Mediated Immune Responses. Front. Immunol. 2014, 5, 586. [CrossRef]

140. Lopez-Medina, M.; Perez-Lopez, A.; Alpuche-Aranda, C.; Ortiz-Navarrete, V. Salmonella Induces PD-L1 Expression in B Cells. Immunol. Lett. 2015, 167, 131-140. [CrossRef]

141. Srinivasan, A.; Nanton, M.; Griffin, A.; McSorley, S.J. Culling of Activated CD4 T Cells during Typhoid Is Driven by Salmonella Virulence Genes. J. Immunol. 2009, 182, 7838-7845. [CrossRef]

142. Binder, D.C.; Engels, B.; Arina, A.; Yu, P.; Slauch, J.M.; Fu, Y.-X.; Karrison, T.; Burnette, B.; Idel, C.; Zhao, M.; et al. Antigen-Specific Bacterial Vaccine Combined with Anti-PD-L1 Rescues Dysfunctional Endogenous T Cells to Reject Long-Established Cancer. Cancer Immunol. Res. 2013, 1, 123-133. [CrossRef]

143. Zhao, T.; Wei, T.; Guo, J.; Wang, Y.; Shi, X.; Guo, S.; Jia, X.; Jia, H.; Feng, Z. PD-1-siRNA delivered by attenuated Salmonella enhances the antimelanoma effect of pimozide. Cell Death Dis. 2019, 10, 164. [CrossRef]

144. Zhao, T.; Feng, Y.; Guo, M.; Zhang, C.; Wu, Q.; Chen, J.; Guo, S.; Liu, S.; Zhou, Q.; Wang, Z.; et al. Combination of attenuated Salmonella carrying PD-1 siRNA with nifuroxazide for colon cancer therapy. J. Cell. Biochem. 2020, 121, 1973-1985. [CrossRef]

145. Phan, T.; Nguyen, V.H.; D’Alincourt, M.S.; Manuel, E.R.; Kaltcheva, T.; Tsai, W.; Blazar, B.R.; Diamond, D.J.; Melstrom, L.G. Salmonella-mediated therapy targeting indoleamine 2, 3-dioxygenase 1 (IDO) activates innate immunity and mitigates colorectal cancer growth. Cancer Gene Ther. 2020, 27, 235-245. [CrossRef]

146. Rosenberg, S.A. IL-2: The First Effective Immunotherapy for Human Cancer. J. Immunol. 2014, 192, 5451-5458. [CrossRef]

147. Treatment of Hairy Cell Leukemia with Recombinant Alpha-Interferon-PubMed. Available online: https://pubmed.ncbi.nlm. nih.gov/3730612/ (accessed on 10 June 2021).

148. Abbott, M.; Ustoyev, Y. Cancer and the Immune System: The History and Background of Immunotherapy. Semin. Oncol. Nurs. 2019, 35, 150923. [CrossRef] 
149. Saltzman, D.A.; Katsanis, E.; Heise, C.P.; Hasz, D.E.; Vigdorovich, V.; Kelly, S.M.; Curtiss, R.; Leonard, A.S.; Anderson, P.M. Antitumor mechanisms of attenuated Salmonella typhimurium containing the gene for human interleukin-2: A novel antitumor agent? J. Pediatr. Surg. 1997, 32, 301-306. [CrossRef]

150. Sorenson, B.S.; Banton, K.L.; Frykman, N.L.; Leonard, A.S.; Saltzman, D.A. Attenuated Salmonella typhimurium with IL-2 Gene Reduces Pulmonary Metastases in Murine Osteosarcoma. Clin. Orthop. Relat. Res. 2008, 466, 1285-1291. [CrossRef]

151. Fritz, S.E.; Henson, M.S.; Greengard, E.; Winter, A.L.; Stuebner, K.M.; Yoon, U.; Wilk, V.L.; Borgatti, A.; Augustin, L.B.; Modiano, J.; et al. A phase I clinical study to evaluate safety of orally administered, genetically engineered Salmonella enterica serovar Typhimurium for canine osteosarcoma. Veter- Med. Sci. 2016, 2, 179-190. [CrossRef]

152. Gniadek, T.J.; Augustin, L.; Schottel, J.; Leonard, A.; Saltzman, D.; Greeno, E.; Batist, G. A Phase I, Dose Escalation, Single Dose Trial of Oral Attenuated Salmonella typhimurium Containing Human IL-2 in Patients With Metastatic Gastrointestinal Cancers. J. Immunother. 2020, 43, 217-221. [CrossRef]

153. Yoon, W.; Park, Y.C.; Kim, J.; Chae, Y.S.; Byeon, J.; Min, S.-H.; Park, S.; Yoo, Y.; Park, Y.K.; Kim, B.M. Application of genetically engineered Salmonella typhimurium for interferon-gamma-induced therapy against melanoma. Eur. J. Cancer 2017, 70, 48-61. [CrossRef]

154. Yoon, W.S.; Chae, Y.S.; Hong, J.; Park, Y.K. Antitumor therapeutic effects of a genetically engineered Salmonella typhimurium harboring TNF- $\alpha$ in mice. Appl. Microbiol. Biotechnol. 2010, 89, 1807-1819. [CrossRef]

155. Loeffler, M.; Le'Negrate, G.; Krajewska, M.; Reed, J.C. Salmonella typhimurium engineered to produce CCL21 inhibit tumor growth. Cancer Immunol. Immunother. 2008, 58, 769-775. [CrossRef]

156. Agorio, C.; Schreiber, F.; Sheppard, M.; Mastroeni, P.; Fernandez, M.; Martínez, M.Á.; Chabalgoity, J.A. Live attenuated Salmonella as a vector for oral cytokine gene therapy in melanoma. J. Gene Med. 2007, 9, 416-423. [CrossRef]

157. Loeffler, M.; Le'Negrate, G.; Krajewska, M.; Reed, J.C. Attenuated Salmonella engineered to produce human cytokine LIGHT inhibit tumor growth. Proc. Natl. Acad. Sci. USA 2007, 104, 12879-12883. [CrossRef]

158. Yuhua, L.; Kunyuan, G.; Hui, C.; Yongmei, X.; Chaoyang, S.; Xun, T.; Daming, R. Oral cytokine gene therapy against murine tumor using attenuated Salmonella typhimurium. Int. J. Cancer 2001, 94, 438-443. [CrossRef]

159. Loeffler, M.; Le'Negrate, G.; Krajewska, M.; Reed, J.C. IL-18-producing Salmonella inhibit tumor growth. Cancer Gene Ther. 2008, 15, 787-794. [CrossRef]

160. Binder, D.C.; Arina, A.; Wen, F.; Tu, T.; Zhao, M.; Hoffman, R.M.; Wainwright, D.A.; Schreiber, H. Tumor relapse prevented by combining adoptive T cell therapy with Salmonella typhimurium. Oncoimmunology 2016, 5, e1130207. [CrossRef]

161. Hiroshima, Y.; Zhang, Y.; Murakami, T.; Maawy, A.; Miwa, S.; Yamamoto, M.; Yano, S.; Sato, S.; Momiyama, M.; Mori, R.; et al Efficacy of tumor-targeting Salmonella typhimurium A1-R in combination with anti-angiogenesis therapy on a pancreatic cancer patient-derived orthotopic xenograft (PDOX) and cell line mouse models. Oncotarget 2014, 5, 12346-12357. [CrossRef]

162. Igarashi, K.; Kawaguchi, K.; Zhao, M.; Kiyuna, T.; Miyake, K.; Miyake, M.; Nelson, S.D.; Dry, S.M.; Li, Y.; Yamamoto, N.; et al. Exquisite Tumor Targeting by Salmonella A1-R in Combination with Caffeine and Valproic Acid Regresses an Adult Pleomorphic Rhabdomyosarcoma Patient-Derived Orthotopic Xenograft Mouse Model. Transl. Oncol. 2020, 13, 393-400. [CrossRef]

163. Zhang, Y.; Zhang, N.; Su, S.; Hoffman, R.M.; Zhao, M. Salmonella typhimurium A1-R tumor targeting in immunocompetent mice is enhanced by a traditional Chinese medicine herbal mixture. Anticancer. Res. 2013, 33, 1837-1843.

164. Garcia-Hernandez, M.D.L.L.; Hamada, H.; Reome, J.B.; Misra, S.K.; Tighe, M.P.; Dutton, R.W. Adoptive Transfer of Tumor-Specific Tc17 Effector T Cells Controls the Growth of B16 Melanoma in Mice. J. Immunol. 2010, 184, 4215-4227. [CrossRef]

165. Safety Study of Clostridium Novyi-NT Spores to Treat Patients With Solid Tumors That Have Not Responded to Standard Therapies-Full Text View_ClinicalTrials.Gov. Available online: https:/ / clinicaltrials.gov/ct2/show/NCT01118819 (accessed on 14 June 2021).

166. Safety Study of Intratumoral Injection of Clostridium Novyi-NT Spores to Treat Patients With Solid Tumors That Have Not Responded to Standard Therapies-Full Text View-ClinicalTrials.Gov. Available online: https://clinicaltrials.gov/ct2/show / NCT01924689 (accessed on 14 June 2021).

167. One Time Injection of Bacteria to Treat Solid Tumors That Have Not Responded to Standard Therapy-Full Text ViewClinicalTrials.Gov. Available online: https:/ / clinicaltrials.gov/ct2/show /NCT00358397 (accessed on 14 June 2021).

168. Roberts, N.; Zhang, L.; Janku, F.; Collins, A.; Bai, R.-Y.; Staedtke, V.; Rusk, A.W.; Tung, D.; Miller, M.; Roix, J.; et al. Intratumoral injection of Clostridium novyi-NT spores induces antitumor responses. Sci. Transl. Med. 2014, 6, 249ra111. [CrossRef] [PubMed]

169. Toso, J.F.; Gill, V.J.; Hwu, P.; Marincola, F.M.; Restifo, N.P.; Schwartzentruber, D.J.; Sherry, R.M.; Topalian, S.L.; Yang, J.C.; Stock, F.; et al. Phase I Study of the Intravenous Administration of Attenuated Salmonella typhimurium to Patients With Metastatic Melanoma. J. Clin. Oncol. 2002, 20, 142-152. [CrossRef] [PubMed]

170. Heimann, D.M.; Rosenberg, S.A. Continuous Intravenous Administration of Live Genetically Modified Salmonella Typhimurium in Patients With Metastatic Melanoma. J. Immunother. 2003, 26, 179-180. [CrossRef] [PubMed]

171. Nemunaitis, J.; Cunningham, C.; Senzer, N.; Kuhn, J.; Cramm, J.; Litz, C.; Cavagnolo, R.; Cahill, A.; Clairmont, C.; Sznol, M. Pilot trial of genetically modified, attenuated Salmonella expressing the E. coli cytosine deaminase gene in refractory cancer patients. Cancer Gene Ther. 2003, 10, 737-744. [CrossRef] 
172. Schmitz-Winnenthal, F.H.; Hohmann, N.; Schmidt, T.; Podola, L.; Friedrich, T.; Lubenau, H.; Springer, M.; Wieckowski, S.; Breiner, K.M.; Mikus, G.; et al. A phase 1 trial extension to assess immunologic efficacy and safety of prime-boost vaccination with VXM01, an oral T cell vaccine against VEGFR2, in patients with advanced pancreatic cancer. OncoImmunology 2017, 7, e1303584. [CrossRef]

173. Duong, M.T.-Q.; Qin, Y.; You, S.-H.; Min, J.-J. Bacteria-cancer interactions: Bacteria-based cancer therapy. Exp. Mol. Med. 2019, 51, 1-15. [CrossRef]

174. Broadway, K.M.; Denson, E.A.; Jensen, R.V.; Scharf, B.E. Rescuing chemotaxis of the anticancer agent Salmonella enterica serovar Typhimurium VNP20009. J. Biotechnol. 2015, 211, 117-120. [CrossRef]

175. VNP20009 in Treating Patients With Advanced or Metastatic Solid Tumors That Have Not Responded to Previous Therapy-Full Text View-ClinicalTrials.Gov. Available online: https: / www.clinicaltrials.gov / ct2/show / NCT00004216?term=Salmonella\& cond=Cancer\&draw $=2 \&$ rank $=5$ (accessed on 1 May 2021).

176. Treatment of Patients With Cancer With Genetically Modified Salmonella Typhimurium Bacteria-Full Text ViewClinicalTrials.Gov. Available online: https://www.clinicaltrials.gov/ct2/show / NCT00004988?term=Salmonella\&cond= Cancer\&draw $=2 \&$ rank $=2$ (accessed on 1 May 2021).

177. VNP20009 in Treating Patients With Advanced Solid Tumors-Tabular View-ClinicalTrials.Gov. Available online: https: / / www.clinicaltrials.gov / ct2/show / record / NCT00006254?term=Salmonella\&cond=Cancer\&draw=2\&rank=3 (accessed on 1 May 2021).

178. IL-2 Expressing, Attenuated Salmonella Typhimurium in Unresectable Hepatic Spread—Full Text View-ClinicalTrials.Gov. Available online: https: / www.clinicaltrials.gov/ct2/ show / NCT01099631?term=Salmonella\&cond=Cancer\&draw=2\&rank=4 (accessed on 1 May 2021).

179. VXM01 Phase I Dose Escalation Study in Patients With Locally Advanced, Inoperable and Stage IV Pancreatic Cancer-Full Text View_ClinicalTrials.Gov. Available online: https:/ / clinicaltrials.gov/ct2/show/NCT01486329 (accessed on 1 May 2021).

180. Multiple Myeloma Trial of Orally Administered Salmonella Based Survivin Vaccine-Full Text View-ClinicalTrials.Gov. Available online: https: / / www.clinicaltrials.gov / ct2/ show / NCT03762291?term=Salmonella\&cond=Cancer\&draw=2\&rank=7 (accessed on 1 May 2021).

181. DNA Vaccination Against Neuroblastoma-Full Text View-ClinicalTrials.Gov. Available online: https://www.clinicaltrials. gov/ct2/show / NCT04049864?term=Salmonella\&cond=Cancer\&draw=2\&rank=8 (accessed on 1 May 2021).

182. Saltikva for Metastatic Pancreatic Cancer-Full Text View-ClinicalTrials.Gov. Available online: https:/ / www.clinicaltrials.gov / ct2/show / NCT04589234?term=Salmonella\&cond=Cancer\&draw=2\&rank=1 (accessed on 1 May 2021).

183. Felgner, S.; Kocijancic, D.; Frahm, M.; Weiss, S. Bacteria in Cancer Therapy: Renaissance of an Old Concept. Int. J. Microbiol. 2016, 2016, 1-14. [CrossRef]

184. Frahm, M.; Felgner, S.; Kocijancic, D.; Rohde, M.; Hensel, M.; Curtiss, R.; Erhardt, M.; Weiss, S. Efficiency of Conditionally Attenuated Salmonella enterica Serovar Typhimurium in Bacterium-Mediated Tumor Therapy. mBio 2015, 6, e00254-15. [CrossRef]

185. Mignon, C.; Sodoyer, R.; Werle, B. Antibiotic-Free Selection in Biotherapeutics: Now and Forever. Pathogens 2015, 4, 157-181. [CrossRef]

186. Forbes, N.S.; Coffin, R.S.; Deng, L.; Evgin, L.; Fiering, S.; Giacalone, M.; Gravekamp, C.; Gulley, J.L.; Gunn, H.; Hoffman, R.M.; et al. White paper on microbial anti-cancer therapy and prevention. J. Immunother. Cancer 2018, 6, 78. [CrossRef]

187. Zhang, Y.; Cao, W.; Toneri, M.; Zhang, N.; Kiyuna, T.; Murakami, T.; Nelson, S.D.; Dry, S.M.; Li, Y.; Li, S.; et al. Toxicology and efficacy of tumor-targeting Salmonella typhimurium A1-R compared to VNP 20009 in a syngeneic mouse tumor model in immunocompetent mice. Oncotarget 2017, 8, 54616-54628. [CrossRef]

188. Low, K.B.; Ittensohn, M.; Luo, X.; Zheng, L.M.; King, I.; Pawelek, J.M.; Bermudes, D. Construction of VNP20009: A Novel, Genetically Stable Antibiotic-Sensitive Strain of Tumor-Targeting Salmonella for Parenteral Administration in Humans. Methods Mol. Med. 2004, 90, 47-60. [CrossRef]

189. Zhao, M.; Yang, M.; Ma, H.; Li, X.; Tan, X.; Li, S.; Yang, Z.; Hoffman, R.M. Targeted Therapy with a Salmonella Typhimurium Leucine-Arginine Auxotroph Cures Orthotopic Human Breast Tumors in Nude Mice. Cancer Res. 2006, 66, 7647-7652. [CrossRef]

190. Hoffman, R.M. Tumor-Targeting Salmonella typhimurium A1-R: An Overview. Adv. Struct. Saf. Stud. 2016, 1409, 1-8. [CrossRef]

191. Felgner, S.; Kocijancic, D.; Frahm, M.; Heise, U.; Rohde, M.; Zimmermann, K.; Falk, C.; Erhardt, M.; Weiss, S. Engineered Salmonella enterica serovar Typhimurium overcomes limitations of anti-bacterial immunity in bacteria-mediated tumor therapy. OncoImmunology 2017, 7, e1382791. [CrossRef]

192. Din, M.O.; Danino, T.; Prindle, A.; Skalak, M.; Selimkhanov, J.; Allen, K.; Julio, E.; Atolia, E.; Tsimring, L.S.; Bhatia, S.N.; et al. Synchronized Cycles of Bacterial Lysis for in vivo Delivery. Nature 2016, 536, 81-85. [CrossRef]

193. Mercado-Lubo, R.; Zhang, Y.; Zhao, L.; Rossi, K.; Wu, X.; Zou, Y.; Castillo, A.; Leonard, J.; Bortell, R.; Greiner, D.L.; et al. A Salmonella nanoparticle mimic overcomes multidrug resistance in tumours. Nat. Commun. 2016, 7, 12225. [CrossRef]

194. Mi, Z.; Guo, L.; Liu, P.; Qi, Y.; Feng, Z.; Liu, J.; He, Z.; Yang, X.; Jiang, S.; Wu, J.; et al. “Trojan Horse” Salmonella Enabling Tumor Homing of Silver Nanoparticles via Neutrophil Infiltration for Synergistic Tumor Therapy and Enhanced Biosafety. Nano Lett. 2021, 21, 414-423. [CrossRef] 